\title{
Plants Diversity of the Burigi-Chato National Park: Rare and Invasive Species
}

\author{
John E. Makunga*, Alfred Gobolo \\ Pasiansi Wildlife Training Institute, Department of Wildlife Management and Law Enforcement, Mwanza, Tanzania \\ Email: ^jmakunga1@gmail.com, jmakunga@pasiansiwildlife.ac.tz, alfredgobolo@gmail.com
}

How to cite this paper: Makunga, J. E., \& Gobolo, A. (2020). Plants Diversity of the Burigi-Chato National Park: Rare and Invasive Species. Open Journal of Forestry, 10, 232-263.

https://doi.org/10.4236/ojf.2020.102016

Received: February 27, 2020

Accepted: April 14, 2020

Published: April 17, 2020

Copyright $\odot 2020$ by author(s) and Scientific Research Publishing Inc. This work is licensed under the Creative Commons Attribution International License (CC BY 4.0).

http://creativecommons.org/licenses/by/4.0/

(c) (i) Open Access

\begin{abstract}
This study was conducted within a distance of three to five kilometres around Lake Burigi as a study area in the Burigi-Chato National Park for the purpose of documenting the diversity of plants, identifying invasive and rare species for enhancing conservation in the park. Lake Burigi was purposively sampled as a study area for plant identification due to its potential as a tourist destination. No study has been conducted in the study area to reveal plants diversity, with a focus on documenting invasive and rare species, thus necessitating undertaking of this study to inform the park authority to take urgent control measures in avoiding widespread of invasive species and proper planning for conservation of rare species. The methods involved included field observation; plant identification using field guide books, indigenous and professional knowledge; field mapping using GPS receiver and literature reviews. Analysis of meteorological data and soil sample were also used among other methods. Meteorological data were analysed using Microsoft Excel and SPSS v.20 to determine the relationship between variables. A total of 102 plant species of different growth forms of trees, shrubs, grasses, sedges, forbs, and herbs were identified and recorded. Tegetes minuta and Argemone mexicana were recorded as invasive plant species, while six rare plant species potential for pharmaceutical industry; Zanthoxylum usambarense, Gardenia ternifolia, Faidherbia albida, Harrisonia abyssinica, Anona senegalensis, and, Pappea capensis were also recorded. Scars of wildfires were observed in the study area. The study area received an average rainfall of $964.36 \mathrm{~mm}$ per year, the highest peak recorded in 1951. The trend of rainfall showed that many years had rainfall below the average while the temperature was found to increase from year to year, the situation which suggests the existence of climate change in the study area. There was a weak negative relationship between temperature and wind speed. Soil nutrients and disturbances in the area were found to favour the growth of Tegetes minuta. Findings of this study would help ecological unit in the park to conduct regular ecological assessment for the
\end{abstract}


purpose of controlling invasive plant species, which if left to flourish are likely to reduce habitat suitability for ungulates to utilize the area. Moreover, knowing which plant species are rare, adds value to the area as a destination to visitors interested in plants. The findings also allow the park authority to keep record of species rarity and thus easily take control of them to avoid unintended exploitation. Based on the findings, it was concluded that a number of disturbances, meteorological and edaphic factors favour the growth of invasive species. Urgent measures are to be taken to control the observed invasive plant species before they are left to spread in the park to avoid destruction of the habitat suitability and incurring unnecessary expenses and time in combating them. Furthermore, rare plant species especially those with pharmaceutical and industrial values are to be conserved with special attention to ensure their continued survival. It was recommended that humaninduced activities should be prevented through regular ecological assessment, field patrols and public awareness programs. A similar study needs to be conducted during dry season to make comparison of the capacity of plants in adapting to different changes of the weather.

\section{Keywords}

Invasive Species, Rare Species, Plant Identification, Burigi-Chato National Park

\section{Introduction}

Plants are the most important components of the environment for the immense roles they perform. They are the producers of nutrients and energy to support the trophic levels in wildlife conservation areas. Lack of enough knowledge on plants identification and documentation of types of plant species available in protected areas has resulted in drastic decline or extinction of certain species or upsurge of invasive species in a particular area. Biological invasion has grown tremendously in the past 50 years (Pysek et al., 2006) and has become an important multi-dis- ciplinary in the field of ecology. Biological invasions threaten the integrity of many ecosystems and are considered second only to habitat destruction in their effects on biodiversity and on landscapes as the whole (Runyon et al., 2012).

From a vegetation management perspective, it is important to know a plant's identity to determine if it is a weed and the level of risk it poses to desired vegetation. Identification is especially important for early detection of new invasive species that have never been documented in an area before and can be targeted for eradication (Mangold, 2018). Plant identification (Mangold, 2018) is also important for people who raise livestock and are concerned about their animals eating toxic plants. Additionally, knowing what plant, you are about to eat something from a wild plant could become a matter of life or death.

Like many areas globally, invasive species in the dry forests and rangelands (which are hereafter jointly referred to as drylands) of East Africa have been in- 
troduced both intentionally and accidentally and are damaging the natural and man-made ecosystems. In East Africa, and particularly Kenya, pastoralists have been adversely affected by invasive plant species and is a disaster registered in many communities (Obiri, 2011). Recent information revealed that over 60 invasive species have been recorded in different National Parks in Tanzania (TANAPA, 2020).

By definition, invasive alien species refer to alien species whose establishment and spread threaten ecosystems, habitats or species with economic or environmental harm. These are addressed under Article $8(\mathrm{~h})$ of the Convention on Biological Diversity (CBD, 1992). Invasive alien species were also defined (CBD News, 2001) as species introduced deliberately or unintentionally outside their natural habitats where they have the ability to establish themselves, invade, out-compete natives and take over the new environments. Invasive plant species largely flourish in conditions resulting from the complex interactions (disturbed areas) among natural and anthropogenic factors such as native and non-native pests, fires, droughts, wind storms, climate warming, management practices, human travel, and trade (Dix, 2009).

Invasive species (Pyšek and David, 2010) are a major element of global change and are contributing to biodiversity loss, ecosystem degradation, and impairment of ecosystem services worldwide. Strong allelopathic effects of invasive plant species on native plants are frequently observed when the plants in the introduced range did not co-evolve with the invader (Chen et al., 2017). Exotic invasive plants exclude/replace the native plant species by direct interference, that is to say, using competition and allelopathy mechanisms (Chen et al., 2017).

The overwhelmed management of the Burigi-Biharamulo-Kimisi (BBK) Game Reserves (currently, Burigi-Chato National Park) created an opportunity for the refugees to freely enter the reserves en-masse plundering and depleting the resources with no respect for Tanzanian laws (MNRT, 2005). Environmental impacts of refugees on forests resulting in deforestation and degradation of surrounding woodlands were due to the high demand for building poles and fuel wood (Jambiya et al., 2007). As a result of environmental consequences caused by refugees from neighbouring countries, the probability of deteriorating rare plant species, especially those with renown for medicinal values and perhaps introduction and distribution of invasive species, would have increased in the area.

Lack of previous documentation of vegetation types and status in the former BBK Game Reserve which has recently upgraded status of Burigi-Chato National Park makes this study important in establishing a baseline on the type and status of vegetation present in the park that would require close monitoring and management. Such baseline is imperative in the conservation arena as it allows management of habitat for its suitability to ungulates; management of rare plant species that are vulnerable to extinction due to human activities if carefully monitored; and planning for prevention and control measures against invasive species that are typically invaders and therefore not palatable to grazers. 
The management of Burigi-Chato has done little in resource inventory. Although several studies being conducted in the study area, such as Jambiya et al. (2007), Mutagwaba (2010) and Masalu (2008), neither of them has reported on plant identification, rare species nor presence of invasive species. This study was therefore, concerned with plant identification; documentation of rare plant species and invasive plant species in the area.

\section{Materials and Methodology}

\subsection{Study Area}

The study was conducted in Burigi-Chato National Park, around Lake Burigi at Burigi One Camp moving about three to five kilometres (in some places) in the terrestrial ecosystem (Figure 1). The study area lies between the grid reference $9,760,000 \mathrm{~N}$ and 9,770,000N and between 300,000E and 310,000E. Burigi-Chato National Park is among twenty two national parks in Tanzania. The park is one of the five newly gazetted National Parks in the country, following upgrading of some of the existing Game Reserves, managed by the Tanzania Wildlife Management Authority (TAWA).

Geographically, Burigi-Chato National Park (formed by Burigi, Biharamulo and Kimisi) is situated in the North-western part of Tanzania covering Kagera and Geita regions, and its total area coverage is $4702 \mathrm{~km}^{2}$ (Jambiya et al., 2007). The park was established in July 2019 after upgrading three Game Reserves of Burigi-Biharamulo-Kimisi (BBK), which were established in the 1970s (Assistant Conservation Commissioner, 2019).

Burigi-Chato National Park, is located within the boundaries of Biharamulo, Karagwe and Chato Districts in Tanzania and lies at an altitude of $1000-1500 \mathrm{~m}$ from the sea level (Masuki \& Mbogoni, 2016). Several lakes found in Burigi-Chato National Park are Burigi, Ngoma, Nyamalebe, Kasinga/Nyarwambaire and small portions of Lake Victoria, which are permanent water sources, which supports wildlife as well as a variety of aquatic species (Assistant Conservation Commissioner, 2019).

Lake Burigi (the largest of lakes in the park) has water with approximately maximum of $4 \mathrm{~km}$ wide, $27 \mathrm{~km}$ length and at least $8 \mathrm{~m}$ deep. The water is saline as one approaches the shore and becomes fresh as one moves interior the lake (Kulekana, 2004). The $\mathrm{pH}$ for water in this lake ranges between 8.5 - 8.3 (Kiss, 1977; Kulekana, 2004; Mutagwaba, 2010). In terms of topography, the area has undulating to rolling plains, while the dominant soils are Haplic Ferralsols, which is the low soil fertility. The park has diverse vegetation types including forests, thickets, woodlands, shrublands, bushlands, grasslands and swamps.

Administratively the Burigi-Chato National Park is located in Kagera region within Muleba, Ngara, Biharamulo districts and Geita region, within Chato district and is ranked the third National Park in Tanzania after Ruaha and Serengeti National Parks which ranks number one and two respectively in terms of the size (Wild Taina Safaris, 2019). 


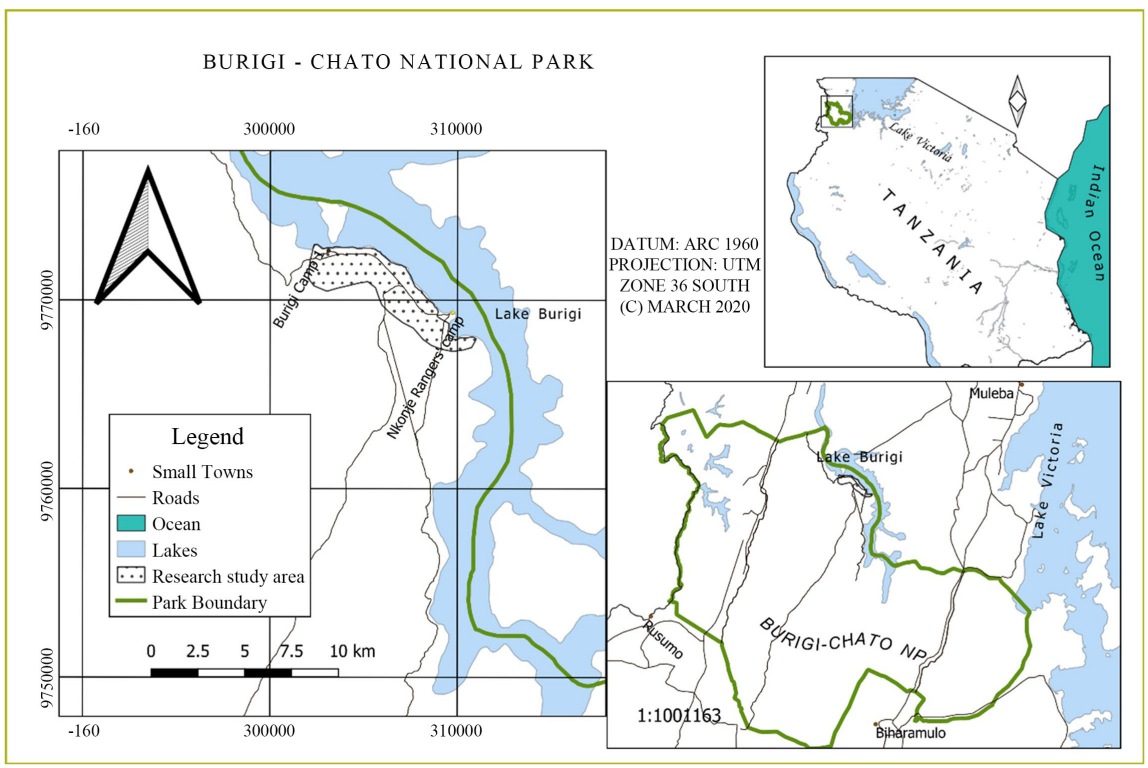

Figure 1. A study area used for plants identification in Burigi-Chato National Park.

\subsection{Methods}

This study was conducted using site visit as a ground truthing to allow image data (in case used in other studies within the study area) to be related to real features and materials on the ground. Digital photographs were also taken for identified plant species of potential significance to help in a checklist preparation for the park management. This study was undertaken between October and December 2019, during the rainy season climate. The study area was selected using a purposive sampling approach, based on the criterion of the potentiality of the area in harbouring biological diversity, both flora and fauna which need special conservation measures as one of the tourists' destination in the park.

Several methods were employed during this study including field observation and identification; coordinates recording using a hand-held global positioning system (GPS) device to record invasive and rare plant species at some locations thus, allowing close follow up by park ecologists, researchers, park authority or tourists interested in plants. Methods also included analysis of meteorological data, which were analyzed using Microsoft Excel and SPSS v.20 for establishing relationship between variables and facilitating easy interpretation of meteorological phenomena in the area.

Another method was literature reviews using online resources and printed materials to acquire information that would confirm scientific names for some plant species, their families as well as their pertinent common names. Analysis of soil samples collected by other studies were also used to establish the relationship between edaphic factors and growth of invasive species. A number of different plants field guides were used to identify species encountered within the sampled area to help close comparison of the already documented plant species with those observed in the field. Professional knowledge was also employed in identification some common plants species. 


\section{Results}

Plants of different growth forms including trees, shrubs, grasses, sedges, forbs, and herbs were identified. A total of one hundred and two (102) plant species were recorded in a period of two months. Each identified plant was recorded for its English name (common name), scientific name, a family name, local name(s) for some plants as well as the status, whether the plant was a common in the area, invasive or rare.

During the study, six (6) rare species recorded. A total of six rare plant species, equal to $5.8 \%$ of the identified plants namely, the Knob-wood tree (Zanthoxylum usambarense), Large-leaved common gardenia (Gardenia ternifolia), Faidherbia albida, Harrisonia abyssinica, Anona senegalensis, and, Pappea capensis were recorded.

Apart from rare species, two hazardous invasive plants species were also identified, including; Tegetes minuta and Argemone mexicana whose proportion was $1.9 \%$ of the total identified plants. Tegetes minuta was recorded with GPS coordinates (in some places) including 36M TN 80169, MGRS 11672 and 36M TN 80188, MGRS 11690.

Scars of wildfires were observed at different sites indicating presence of human-induced activities previously conducted in the area. Additionally, many plants that were observed to be affected by wildfires were at their young stages of growth. If no consideration of conservation measures to control such unplanned fires there is a great likelihood of extinction of some plant species especially which are rare.

Through field observation, the area was found to be susceptible to wildfires during drought seasons as many plants were found struggling to recover from tissues damages caused by fires. Black scars resulting from such fires were observed on tree stumps of many identified plants thus justifying previous wildfire incidences in the park.

\subsection{Plant Species Identified in Burigi-Chato National Park}

During field visit, 102 plant species (see Table 1) of different growth forms such as grasses, herbs, forbs, shrubs and succulent plants were identified and recorded. Although professional knowledge and experience were vital in plant identification, indigenous knowledge was of paramount importance during the exercise for easy identification of plants using traditional or local names. Some of these tribes were Kara, Jita, Kurya, Luo and Sukuma (Lake Zone), Masaai, Pare, Chagga and Iraq (Northern Tanzania) and others such as Nyaturu and Gogo (Central Tanzania), Hehe, Bena and Matengo (from Southern regions of Tanzania) as well as Fipa and Nyamwezi in the Western part of the country. Nevertheless, some literatures were also accessed for familiarizing with English names, scientific names and family names: (Dharani, 2006; Roodt, 2005; Yumpu, No Date).

\subsection{Analysis of Rainfall Data in the Study Area}

Rainfall data (Figure 2) for a period of 67 years from 1923 to 1994 collected at Biharamulo whether station was analysed in Excel. However, some data for five 
years (1979, 1987, 1988, 1989 and 1990) were either not complete or missing, therefore they were not analysed. The analysis was meant to explain the climate conditions for the growth of Tegetes minuta in the study area.

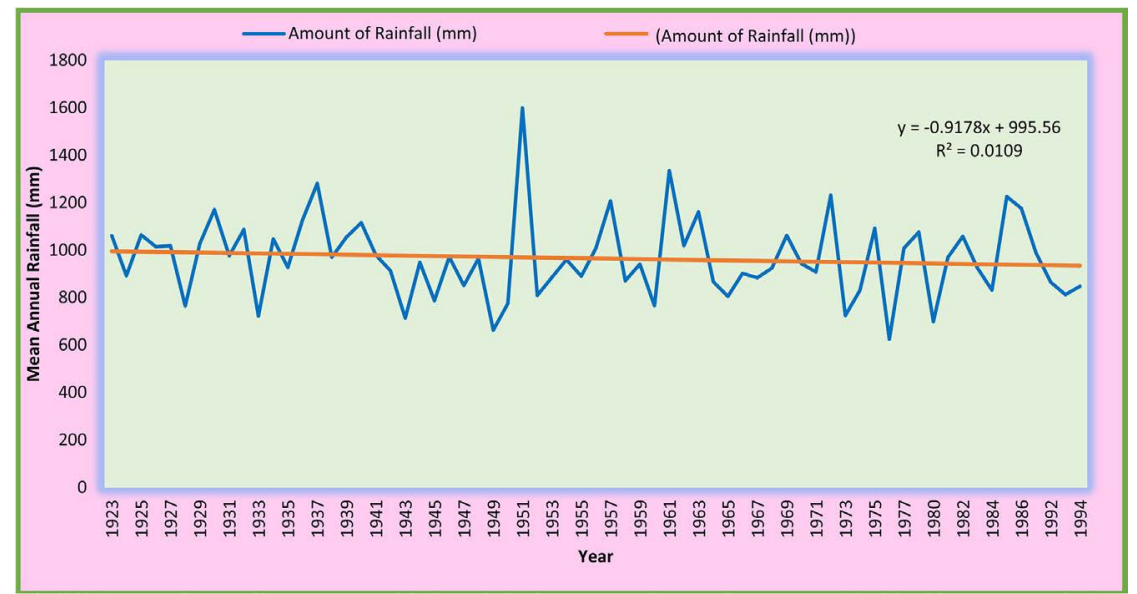

Figure 2. Trend of Rainfall (mm) in Burigi-Chato National Park from 1923-1994.

Source: Tanzania Meteorological Authority (TMA), cited in Oosterom et al. (1999).

Table 1. A Checklist of plant species identified in around Lake Burigi.

\begin{tabular}{|c|c|c|c|c|c|c|}
\hline $\mathrm{SN}$. & English Name & Scientific Name & Family Name & $\begin{array}{l}\text { Plant growth } \\
\text { form }\end{array}$ & Local Name(s) & Status \\
\hline 1. & $\begin{array}{l}\text { Prickly thorn/Wait a bit } \\
\text { thorn }\end{array}$ & Senegalia brevispica & Fabaceae & Shrub & $\begin{array}{l}\text { Ligee (Kijita/Kikara), } \\
\text { Olgirigiri (Maasai), }\end{array}$ & Common \\
\hline 2. & Red acacia/Whistling tree & Vachellia seyal & Fabaceae & Tree & $\begin{array}{l}\text { Linyanya (Kikara/Kijita), } \\
\text { Olchoray, elereta (Maasai) }\end{array}$ & Common \\
\hline 3. & Velvet-leaved combretum & Combretum molle & Combretaceae & Tree & $\begin{array}{l}\text { Lilama (Kikara/Kijita), } \\
\text { Namata (Sukuma) }\end{array}$ & Common \\
\hline 4. & Desert date/soap berry tree & Balanites aegyptiaca & Zygophyllaceae & Tree & $\begin{array}{l}\text { Liluguyu (Kikara/Kijita), } \\
\text { miyuguyu (Sukuma), } \\
\text { Orng'oswa, osaragi (Maasai) }\end{array}$ & Common \\
\hline 5. & Drooping balanites & Balanites grabra & Zygophyllaceae & Tree & $\begin{array}{l}\text { Liluguyu (Kikara/Kijita), } \\
\text { miyuguyu (Sukuma), } \\
\text { Orng'oswa, osaragi (Maasai) }\end{array}$ & Common \\
\hline 6. & $\begin{array}{l}\text { Three-thorned acacia/Gum } \\
\text { Arabic tree }\end{array}$ & Acacia senegal & Fabaceae & Tree & Liluga (Kijita) & Common \\
\hline 7. & Raisin bush/Tar berry & Ozoroa insignis & Anacardiaceae & Tree & Likalakala (Kikara/Kijita) & Common \\
\hline 8. & Ana tree/Apple-ring acacia & Faidherbia albida & Fabaceae & Tree & $\begin{array}{l}\text { Mpogoro (Bena, Hehe), } \\
\text { Mkungugu (Gogo) }\end{array}$ & Rare \\
\hline 9. & Khaki bur/Khaki weed & Alternanthera punges & Amaranthaceae & Creeping forb & Alaimererwani (Maasai) & Common \\
\hline 10. & $\begin{array}{l}\text { Egyptian pea/Egyptian } \\
\text { river hemp }\end{array}$ & Sesbania sesban & Fabaceae & Tree/Shrub & Lilindi (Kikara/Kijita) & Common \\
\hline 11. & $\begin{array}{l}\text { Paper reed/Indian matting } \\
\text { plant }\end{array}$ & Cyperus papyrus & Cyperaceae & Sedge & $\begin{array}{l}\text { Indago (Kijita), eseiyia } \\
\text { (Maasai) }\end{array}$ & Common \\
\hline 12. & $\begin{array}{l}\text { Purple nut sedge/Giant } \\
\text { sedge }\end{array}$ & Cyperus rotundus & Cyperaceae & Sedge & $\begin{array}{l}\text { Indago (Kikara/Kijita), } \\
\text { ndago (Sukuma), oseyai } \\
\text { (Maasai) }\end{array}$ & Common \\
\hline 13. & Great sedge & Cyperus immensus & Cyperaceae & Sedge & $\begin{array}{l}\text { Indago (Kikara/Kijita), } \\
\text { ndago (Sukuma), oseyai } \\
\text { (Maasai) }\end{array}$ & Common \\
\hline
\end{tabular}




\section{Continued}

\begin{tabular}{|c|c|c|c|c|c|c|}
\hline 14. & $\begin{array}{l}\text { Lesser reedmace/ } \\
\text { Narrow-leaved cattail }\end{array}$ & Typha angustifolia & Typhaceae & Sedge & Amabhimbili (Kijita) & Common \\
\hline 15. & $\begin{array}{l}\text { Harrisonia (no English } \\
\text { name) }\end{array}$ & Harrisonia abyssinica & Simaroubaceae & Shrub & Echisawa (Kijita) & Rare \\
\hline 16. & Magic guarri & Euclea dovinorum & Ebanaceae & Shrub & $\begin{array}{l}\text { Nyabhakangala } \\
\text { (Kikara/Kijita), olkinyei } \\
\text { (Maasai) }\end{array}$ & Common \\
\hline 17. & Spike carrot-seed grass & Tragus berteronianus & Poaceae & Grass & Not known & Common \\
\hline 18. & Emilia & Emilia coccinea & Asteraceae & Herb & Not known & Common \\
\hline 19. & Buffalo thorn & Ziziphus mucronata & Rhamnaceae & Shrub & $\begin{array}{l}\text { Ngugunu (Sukuma), } \\
\text { mutanula (Hehe), } \\
\text { Msarakanga (Kurya), } \\
\text { Lango (Luo) }\end{array}$ & Common \\
\hline 20. & Sickle bush/Bell mimosa & Dichrostachys cinerea & Fabaceae & Shrub & $\begin{array}{l}\text { Lisanjawa (Kikara/Kijita), } \\
\text { Tunduru (Sukuma), } \\
\text { enditryakata, olmerumori } \\
\text { (Maasai) }\end{array}$ & Common \\
\hline 21. & Natal rhus & Rhus natalensis & Anacardiaceae & Shrub & $\begin{array}{l}\text { Lisese (Kikara/Kijita), } \\
\text { Omisigiyoi (Maasai) }\end{array}$ & Common \\
\hline 22. & $\begin{array}{l}\text { White-leaved raisin/Raisn } \\
\text { bush }\end{array}$ & Grewia bicolor & Tiliaceae & Shrub & $\begin{array}{l}\text { Echikomakoma } \\
\text { (Kikara/Kijita), nkoma, } \\
\text { mkoma (Sukuma), ositeti } \\
\text { (Maasai) }\end{array}$ & Common \\
\hline 23. & Wild lime/Spiny plum & Ximenia Americana & Olacaceae & Shrub & $\begin{array}{l}\text { Lisyeka (Kikara/Kijita), } \\
\text { Nhundwa (Sukuma), } \\
\text { ormoragi (Maasai) }\end{array}$ & Common \\
\hline 25. & $\begin{array}{l}\text { African myrrh/African } \\
\text { bdellium }\end{array}$ & Commiphora africana & Burseraceae & Shrub & $\begin{array}{l}\text { Elyololo (Kikara/Kijita), } \\
\text { Osilalei (Maasai) }\end{array}$ & Common \\
\hline 26. & Mountain acacia & $\begin{array}{l}\text { Brachystegia } \\
\text { microphylla }\end{array}$ & Fabaceae & Tree & $\begin{array}{l}\text { Muyombo (Hehe), Msani } \\
\text { (Gogo), Mgela (Nyamwezi) }\end{array}$ & Common \\
\hline 27. & Mountain acacia/Redwood & $\begin{array}{l}\text { Brachystegia } \\
\text { tamarindoides }\end{array}$ & Fabaceae & Tree & Nseni (Shambaa) & Common \\
\hline 28. & Sausage tree & Kigeria africana & Bignoniaceae & Tree & $\begin{array}{l}\text { Lijungute (Kikara/Kijita), } \\
\text { mwicha (Sukuma), aldarpoi } \\
\text { (Maasai) }\end{array}$ & Common \\
\hline 29. & Bitter leaf & Vernonia amygdalina & Asteraceae & Herb & Not known & Common \\
\hline 30. & Horseweed/Butterweed & Conyza floribunda & Asteraceae & Herb & Not known & Common \\
\hline 31. & Khaki-clad/Wild marigold & Tegetes minuta & Asteraceae & Herb & $\begin{array}{l}\text { Injaga ya bhekwabhi } \\
\text { (Kikara/Kijita) }\end{array}$ & Invasive \\
\hline 32. & Golden bristle grass & Setalia cephacelata & Poaceae & Grass & Not known & Common \\
\hline 33. & Buffalo grass & Panicum maximum & Poaceae & Grass & Not known & Common \\
\hline 34. & $\begin{array}{l}\text { Bermuda grass/Bahama } \\
\text { grass }\end{array}$ & Cynodon dactylon & Poaceae & Grass & $\begin{array}{l}\text { Olusesegasi (Kikara/Kijita), } \\
\text { Ngobi, enaimuryai, } \\
\text { narikporori (Maasai) }\end{array}$ & Common \\
\hline 35. & Thatching grass & Hyparrhenia rufa & Poaceae & Grass & $\begin{array}{l}\text { Obhunyasi (Kikara/Kijita), } \\
\text { Nhenya, matelengu } \\
\text { (Sukuma), asangari (Maasai) }\end{array}$ & Common \\
\hline
\end{tabular}




\section{Continued}

36. White leonotis

37. Orange leonotis

Leonotis mollisma

Lamiaceae

Bidens pilosa

Asteraceae

Asparagaceae

aethiopicus

asparagus

40. Sodom apple

41. Java Indigo/Bengal

indigo/Natal Indigo

42. Lion's claw

43

Chinese Aloe/Burn

aloe/Indian aloe

44. Fan-leaved bristle grass

45. Wild grape/Tree grape

46. No English name

47. Red amaranth

48. Spiderwisp/African spider flower

49.

$\begin{array}{ll}\text { 50. } & \text { Black spear } \\ \text { grass/Tanglehead }\end{array}$

51. Rhodes grass

52. Benghal dayflower/

Tropical spideworts

53. Elephant's ear/Fluted abutilon

54. Wavy-leaf oxygonum

55. Small-fruited teclea

56
Solanun incanum

Solanaceae

Indigofera arrecta

Fabaceae

Crotalaria agatiflora

Fabaceae

Aloe vera

Setaria homonyma

Poaceae

Cissus rotundifolia

Vitaceae

Cyphostemma

serpens

Vitaceae

Amaranthus

cruensis

Amaranthaceae

Gynandropsis

gynandra

Capparaceae

Poaceae

Dactelocten

Heteroprogon

contortus

Chloris gayana

Poaceae

Poaceae

Commelina

benghalensis

Commelinaceae

Abutilon angulatum Malvaceae

Polygonaceae

Oxygonum

synuatum

Teclea nobilis

Rutaceae

Poaceae
Herb

Herb

Herb

Herb

Herb

Herb

Herb

Grass

Climber

Climber/ succulent plant

Forb

Forb

Grass

Grass

Grass

Forb

Herb

Herb

Shrub

Grass
Amasosonyi (Kikara/Kijita),

zunzu (Sukuma), obibiai, Common engesenii (Maasai)

Amasosonyi (Kikara/Kijita), zunzu (Sukuma), obibiai, Common engesenii (Maasai)

Indasana (Kikara/Kijita), manasa (Sukuma),

Common enderepenyi (Maasai)

Not known

Common

Litobholo (Kikara/Kijita),

Hahngal (Iraaq), Matula

(Sukuma), enduleyeyii

Common (Maasai)

Elyeyo (Kikara/Kijita), entepaa uangayo (Maasai)

Common

Nyabhundege (Kikara/Kijita), Songa (Sukuma)

Nitrification

Inkakaumba (Kikara/Kijita),

Magaka (Sukuma), osukuroy Common (maasai)

Not known

Common

Not known

Common

Ebhilyo bhya wasongo

(Kikara/Kijita), Olorrondo Common (Maasai)

Omchicha (Kikara/Kijita), Engirora, nado (Maasai)

Common

Omuso (Kikara/Kijita), olarashirash (Maasai), amayoa (Iraq)

Common

Not known

Common

Isungu (Kikara/Kijita)

Common

Not known

Common

Liteja (Kikara/Kijita),

engiteteyai (Maasai), kafura Common (Sukuma), nii (Iraq)

Not known

Common

Echisokolo

(Kikara/Kijita)

Common

Not known

Common

Not known

Common 


\section{Continued}

\begin{tabular}{|c|c|c|c|c|c|c|}
\hline 57. & Orchid tree/butterfly tree & Bauhinia variagata & Fabaceae & Tree & $\begin{array}{l}\text { Lisindaga (Kikara/Kijita), } \\
\text { ormotoo (Maasai), } \\
\text { qarengehh (Iraq) }\end{array}$ & Common \\
\hline 58. & $\begin{array}{l}\text { Golden bean tree/Golden } \\
\text { bell-bean }\end{array}$ & Makhamia obtusfolia & Bignoniaceae & Tree & Lisambya (Kikara/Kijita) & Common \\
\hline 59. & Kyob-wood tree & $\begin{array}{l}\text { Zanthoxylum } \\
\text { usambarense }\end{array}$ & Rutaceae & Shrub & $\begin{array}{l}\text { Litalarungu } \\
\text { (Kikara/Kijita), } \\
\text { oloisukiy (Maasai) }\end{array}$ & Rare \\
\hline 60. & Wild sisal & \multicolumn{2}{|c|}{ Sansevieria ehrenbergiiAsparagaceae } & Succulent plant & $\begin{array}{l}\text { Makonge (Sukuma), } \\
\text { oldupai (Maasai) }\end{array}$ & Common \\
\hline 61. & Forest bushwillow & Combretum krausii & Combretaceae & Tree/shrub & Likoyoyo (Kikara/Kijita) & Common \\
\hline 62. & Bitter albizia & Albizia amara & Fabaceae & Tree & $\begin{array}{l}\text { Likalasatu (Kikara/Kijita), } \\
\text { olperelongo (Maasai) }\end{array}$ & Common \\
\hline 63. & Lettuce & Lactuca capensis & Asteraceae & Forb & $\begin{array}{l}\text { Inyamata, inyabhusungu } \\
\text { (Kikara/Kijita), masunga } \\
\text { (Sukuma) }\end{array}$ & Common \\
\hline 64. & Euphorbia/Spurge & $\begin{array}{l}\text { Euphorbia } \\
\text { canderabrum }\end{array}$ & Euphorbiaceae & Succulent tree & Orpopongii (Maasai) & Common \\
\hline 65. & Kangaroo grass/Red grass & Themeda triandra & Poaceae & Grass & Not known & Common \\
\hline 66. & $\begin{array}{l}\text { Mexican poppy/Mexican } \\
\text { prickly poppy }\end{array}$ & Argemone Mexicana & Papaveraceae & Herb & Not known & Invasive \\
\hline 67. & Wild custard apple & Anona senegalensis & Anonaceae & Tree & Likonyo (Kikara/Kijita) & Common \\
\hline 68. & $\begin{array}{l}\text { Small-leaved shepherd's } \\
\text { tree/Boscia }\end{array}$ & Boscia angustifolia & Capparaceae & Shrub & Olerudoi (Maasai) & Rare \\
\hline 69. & $\begin{array}{l}\text { Monkey orange/Wild } \\
\text { orange }\end{array}$ & Strychnos innocua & Loganiaceae & Shrub & $\begin{array}{l}\text { Ligome (Kijita), Olemba } \\
\text { (Luo), Mtonga (Swahili), } \\
\text { Mpundu (Nyamwezi) }\end{array}$ & Common \\
\hline 70. & $\begin{array}{l}\text { Indaba tree/Jacket } \\
\text { plum/Judgement tree }\end{array}$ & Pappea capensis & Sapindaceae & Shrub & $\begin{array}{l}\text { Omumange (Kuyra), } \\
\text { Omangi (Luo), Muhungulu } \\
\text { (Hehe) }\end{array}$ & Rare \\
\hline 71. & Haemorrhage plant & $\begin{array}{l}\text { Aspillia } \\
\text { mossambicensis }\end{array}$ & Asteraceae & Herb & Not known & Common \\
\hline 72. & Woolly caper-bush & Capparis tomentosa & Capparaceae & Shrub & $\begin{array}{l}\text { Luvisu (Nyamwezi), } \\
\text { Mudabwa (Nyaturu), } \\
\text { Mtera (Pare) }\end{array}$ & Common \\
\hline 73. & Coleus Forskohlii & Plectranthus barbatus & Lamiaceae & Forb & Itolo (Chagga) & Common \\
\hline 74. & $\begin{array}{l}\text { Common wild elder/Brittle } \\
\text { wood }\end{array}$ & Nuxia congesta & Stilbaceae & Shrub & $\begin{array}{l}\text { Lopironi (Maasai), } \\
\text { Mgogo (Shambaa) }\end{array}$ & Common \\
\hline 75. & $\begin{array}{l}\text { Long-headed sedge } \\
\text { Ping/Ping }\end{array}$ & Microglossa pyrifolia & Asteraceae & Sedge & Not known & Common \\
\hline 76. & Sycamore fig/Fig mulberry & Ficus sycomorus & Moraceae & Tree & $\begin{array}{l}\text { Likuyu (Kikara/Kijita), } \\
\text { orngaboli (Maasai), nkuyu } \\
\text { (Sukuma) }\end{array}$ & Common \\
\hline 77. & Spurred potato-bush & Phyllanthus engleri & Phyllanthaceae & Shrub & $\begin{array}{l}\text { Mboromi (Nyaturu), } \\
\text { Ngogondi (Sukuma) }\end{array}$ & Common \\
\hline
\end{tabular}


78. African basil/Clove basil

Ocimum gratissimum Lamiaceae

$\begin{array}{ll}\text { 79. } & \text { Rock fig/Petiolate fig } \\ \text { 80. } & \text { Forest num-num } \\ \text { 81. } & \begin{array}{l}\text { Flame lily/tiger claw/Fire } \\ \text { lily }\end{array} \\ \text { 82. } & \text { Creeping ludwigia } \\ \text { 83. } & \begin{array}{l}\text { Large-leaved common } \\ \text { gardenia }\end{array} \\ \text { 84. } & \text { Mapungubwe sida } \\ \text { 85. } & \begin{array}{l}\text { Rose Natal grass/Natal red } \\ \text { top }\end{array}\end{array}$

Ficus petiolaris

Moraceae

Carissa bispinosa

Apocynaceae

Groliossa superba

Cochicaceae

Ludwigia stolonifera

Onagraceae

Gardenia ternifolia

Rubiaceae

Sida ovata

Malvaceae

Melinis repens

Poaceae

Vachellia polyacantha Fabaceae

Ficus thonningii

Moraceae

Syzygium cordatum

Myrtaceae

89. Prickly chaff flower/Devil's
horsewhip

90. Tree grape/Live-long

91. Chaparral tea/Leather croton/Leatherleaf croton

92. Not known

93. Kokwaro

94. Elastic grass/Elastic love grass

95. No English name

96. Pale smartweed; White smartweed

97. Tail flat sedge

98. Giant sensitive tree

99. Sleepy morning

100. Black horehound

101. Common dandelion

102. White eye, Brazilian calla-lily
Achyranthes aspera Amaranthaceae Herb

Lannea discolor Anacardiaceae Shrub

Croton dichogamus Euphorbiaceae

Pterocarpus

tanganyikensis

Celastraceae

Lannea

schweinfurthii var. stuhlmannii

Eraglostis

tenuifolia

Melhania velutina

Poaceae

Malvaceae

Polygonum

lapathifolium

Cyperus elagrostis

Polygonaceae

Cyperaceae

Fabaceae

Mimosa pigra

Waltheria indica

Malvaceae

Ballota nigra

Lamiaceae

Taraxacum officinale Asteraceae

Richardia brasiliensis Rubiaceae
Herb

Tree

Shrub

Herb

Forb

Shrub

Herb

Grass

Tree

Tree

Tree

Tree/shrub

Shrub

Tree

Grass

Herb

Forb

Sedge

Herb

Herb

Herb

Creeping forb

Creeping forb
Nyabhaengele

(Kikara/Kijita),

Ormagirigiriani (Maasai), malumbalumba (Sukuma)

Lisesya (Kikara/Kijita)

Common

Not known

Common

Not known

Common

Not known

Common

Litalama (Kikara/Kijita)

Rare

Common

Infunji (Kikara/Kijita)

Common

Linyandobho

(Kikara/Kijita),

Migu (Sukuma)

Lirumba (Kikara/Kijita)

Msu (Fipa),

Mvungi lulenga (Hehe), Common Mvenge (Matengo)

Olwesha (Kikara/Kijita),

Olekidongo (Maasai)

Common

Inyamnogo (Kikara/Kijita)

Common

Olokirdingai (Maasai), Olwesya (Kikara/Kijita)

Common

Not known

Common

Orpande (Maasai)

Common

Not known

Common

Not known

Common

Not known

Common

Not known

Common

Not known

Common

Not known

Common

Not known

Common

Not known

Common

Common

Based on the 67 years data analysis, it was revealed the study area receives an average of $964.36 \mathrm{~mm}$ per year. The highest peak of rainfall was recorded in 1951, about $1600 \mathrm{~mm}$. High amount of rainfall was also recorded in 1937 and in 
1961 (about 1400 and $1300 \mathrm{~mm}$, respectively). On the other hand, there was a drastic drop in rainfall in 1949 and 1976 where the record indicated about 600 $\mathrm{mm}$. As reported by another study, the park receives bimodal rainfall pattern with a mean annual rainfall of $800 \mathrm{~mm}$ and the temperature regime is intermediate (Masuki \& Mbogoni, 2016).

Rainfall in the study area is generally high although there was some drop down in some years. The study area therefore, provides conducive environment for the Tegetes minuta to survive. This explanation was supported by some studies (CABI International, 2019). For example, it was reported that Tegetes minuta grows well under high soil moisture conditions, although can tolerate low rainfall (CABI International, 2019).

Through analysis of the deviation from the mean monthly rainfall for a period of 69 years (1921 to 1994), months of April and March were observed to receive more rainfall, with November and December also receiving more precipitation. On the contrary, June, July, August and early September are normally dry months. These findings are important when conducting studies that intend to make comparisons of plant diversity and behaviour in response to precipitation. More importantly, this analysis gives a cue for the tourism department in the park to promote the area as a destination for visitors during these dry months for its enormous tourism attractions.

There was observed a small decline of $1.09 \%$ variance around the mean annual rainfall $(964.36 \mathrm{~mm})$ since 1923 to 1994 . Such decline in the trend of rainfall possesses significant negative consequences on biological diversity and rural livelihoods. With unreliable rainfall, the area may experience frequent human-wildlife conflicts as a result of increased water stress, thus augmenting a great demand for water and pastures for both wildlife and livestock. Encroachment of local community for grazing may also intensify if not controlled, the situation which therefore, calls for a focused conservation planning with an emphasis in improved community conservation approach.

Correlation analysis was performed at 0.377 significance level (2-tailed) to explore the relationship between the mean annual temperature $\left({ }^{\circ} \mathrm{C}\right)$ and the mean maximum wind speed $(\mathrm{Km} / \mathrm{h})$. The results revealed a weak negative relationship between the two variables with the Pearson correlation coefficient of -0.296 . However, the coefficient of determination resulted in a small variance (8.7\%) between the two variables. Due to the small sample size of the collected data, the relationship seemed not to be statistically significant as it would be at the traditional $p<0.05$ level. A small rise in temperature in the study area has therefore, been associated with small decrease in the wind speed.

\subsection{Soils Factors for the Growth of Tegetes minuta}

The analysis of Soil samples (Table 2) collected from 15 sites in Biharamulo District in which Burigi-Chato National Park is situated, at an average depth of $25 \mathrm{~cm}$ deep varied quantitatively in terms of soil $\mathrm{pH}$ and different organic matters elements as follows: 
Table 2. Composite topsoil samples in the study area.

\begin{tabular}{cccc}
\hline SN. & Organic matter/compound & Mean value & Unit of measurement \\
\hline 1. & $\mathrm{H}_{2} \mathrm{O}$ & 5.96 & $1: 25$ \\
2. & $\mathrm{KCL}$ & 4.952 & $1: 25$ \\
3. & $\mathrm{Ca}$ & 5.2216 & $(\%)$ \\
4. & $\mathrm{Mg}$ & 2.0368 & $(\%)$ \\
5. & $\mathrm{~K}$ & 1.1012 & $(\mathrm{cmol} / \mathrm{Kg})$ \\
6. & $\mathrm{Na}$ & 0.0252 & $(\mathrm{cmol} / \mathrm{Kg})$ \\
\hline
\end{tabular}

Source: Oosterom et al. (1999).

Trace elements such as Aluminium and Hydrogen were only recorded in five sites whose mean values were $0.958(\mathrm{cmol} / \mathrm{Kg})$ and $0.064(\mathrm{cmol} / \mathrm{Kg})$ respectively. The observed measurements of the composite top soil sample were sufficient to favour the growth of Tegetes minuta in the area. Seven anthropogenic activities that lead to environmental degradation as a result of refugees' influx in BurigiChato National Park (Masalu, 2008) were identified as farming, encroachment for settlements, poaching, wildfires, tree cutting, and grazing.

As reported by some studies (Holm et al., 1997), Tegetes minuta colonizes many places in the tropics and subtropics with the soil $\mathrm{pH}$ ranging from 4.3 to 6.6. It also prefers under high nutrient and high soil moisture conditions. GIS analysis in Burigi protected area (Masalu, 2008) indicated that four wildlife habitats were impacted by refugees namely; riverine forest, woodlands, scrubland and grasslands.

Another study revealed that Tegetes minuta which is a drought tolerant weed (although it prefers areas with enough rainfall) and can establish in waste areas, neglected rangeland and poorly managed fields and survives easily in poor soils hence it colonize waste ground, roadsides, and gardens (CABI International, 2019).

A study conducted in India (Rengasamy et al., 2013) found that most of the plants studied along the road side were invasive plants. According to the study, higher carbon gain (both in biomass and carbon content), larger proportion of photosynthetic tissues, thicker leaves, larger stomatal size, higher stomatal density, and larger leaf vascular tissues were associated with the exotic species.

\subsection{Impact of Climate Change on Invasive Plant Species}

Climate change is altering vital aspects of the environment such as temperature and precipitation, the frequency of extreme weather events, as well as the atmospheric composition and land cover. The temperature, atmospheric concentration of $\mathrm{CO}_{2}$ and available nutrients are the key factors that will drive species survival; changes in these factors will most likely stress the ecosystems and the chances of invasions (Marambe et al., 2009).

The overall impact of existing invasive species may increase or decrease under 
several scenarios of global change driven by greenhouse-gas influenced climate change, increasing carbon dioxide $\left(\mathrm{CO}_{2}\right)$ concentration, increasing nitrogen $(\mathrm{N})$ deposition, and altered disturbance regimes (Dukes and Mooney, 1999; Bradley et al., 2010). Bioclimatic envelope modeling is a valuable tool for predicting species response to climate change, but these models assume that species distribution is static under a given set of climatic conditions (Runyon et al., 2012).

Analysis of the deviation of mean annual rainfall $(963.36 \mathrm{~mm})$ from 67 years rainfall data (Figure 3 ) indicated a clear cut between years which had more precipitation above average and those with shortage of rainfall below average. The analysis revealed that many years have continued to receive low amount of rainfall, at least $50 \mathrm{~mm}$ below average $(964.36 \mathrm{~mm})$. Surprisingly, recent years had shown a significant drop in precipitation as compared to the previous years. By observing the trend of rainfall in the area, it is evident that there is no indication of experiencing more rainfall in the future as it was in the past, instead there is a welcoming drought, which is likely to threaten life in the study area and neighbouring places indiscriminately. With such temperature extremes, there is no doubt that climate change is real taking place in the area, whose negative consequences ought to be realized from an individual family level to policy makers.

Consequences of climate change have been reported by different scholars. Climate change could open up new opportunities for introduced species that could devastate native flora and fauna. Thus concepts of global change need to include consideration of the behaviour and distribution of invasive species. It seems highly likely that invasive species are going to have even more opportunities in the changed future climate than they have at present (McNeely, 2001). Climate change is therefore a pervasive element of the multiple forcing functions which maintain, generate and threaten biodiversity and induce biological invasion. Between 1900s and 1970s, a series of droughts of different magnitudes were experienced in the Serengeti ecosystem with a minimum return period of ten years (FAO, 2010).

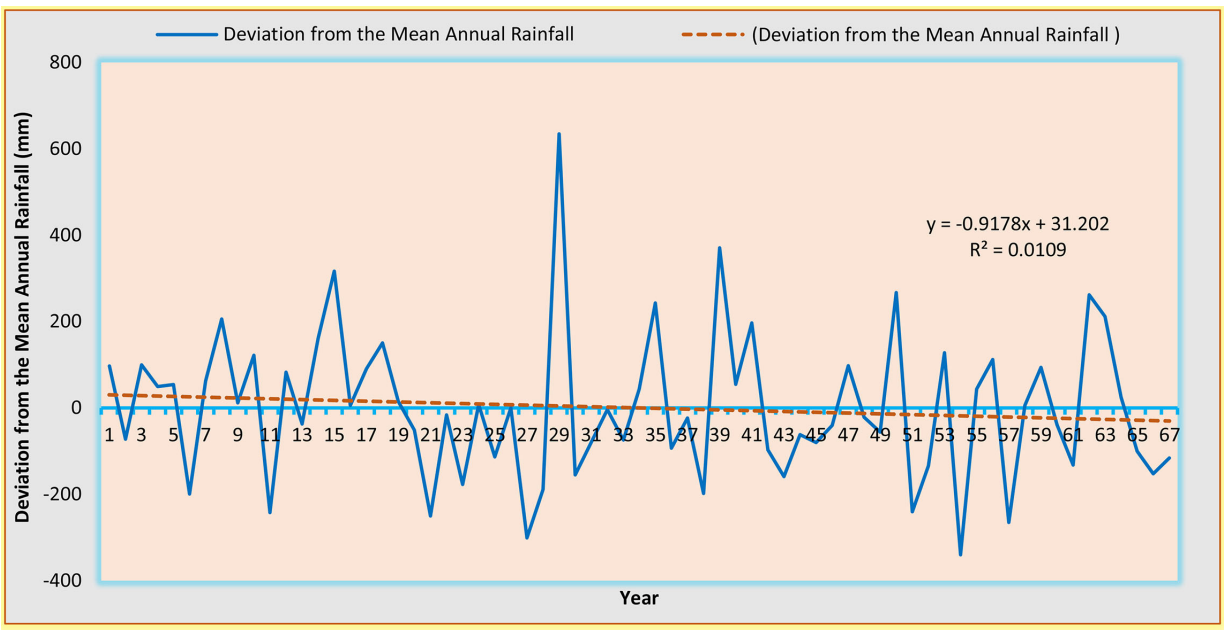

Figure 3. Analysis of Deviation from the Mean Annual Rainfall (mm) from 1923-1994. Source: TMA also cited in Oosterom et al. (1999). 
Due to these extreme events and associated diseases (e.g. rinderpest), the wildebeest population dropped to 200,000 in 1950 s and the migration stopped due to smaller and fragmented wildebeest population (Mduma et al., 1999). Climate indirectly affects nature-based tourism by impacting the physical resources (i.e. land-cover) that define the nature and quality of natural environments on which tourism depends (Scott, 2005).

Normally in extreme climate situations, women (especially widows), children and elders are more vulnerable than men due to their little coping capacity. The observed climate change may therefore, create more difficulties to women living in villages adjacent to the study area than men. In Bangladesh (Terry, 2009), the increased hazard impacts due to climate change have affected more women. The link between poverty and vulnerability is clearly crucial, and affects women disproportionately. If there is no serious progress in reducing poverty in Bangladesh, then it can be assumed that women will become increasingly affected by the impact of intensified hazards, in terms of their ability to resist and recover from them (Terry, 2009).

While there is a slow decrease of rainfall (Figure 2), generally, there is sharp upsurge of variation around the mean annual temperature $\left(19.92^{\circ} \mathrm{C}\right)$ for eleven years (Figure 4) in the study area as revealed by the coefficient of determination of 0.663 . With such trend, climate adaptation and mitigation measures pertinent to drought are to be incorporated into conservation planning, otherwise, conservation efforts in the study area (even in the nearby protected areas) will be in jeopardy.

In explaining the impacts of extreme temperatures, scholarly views (USAID, 2012), found that mixed rain-fed and highland perennial systems in the Great Lakes region and other parts of Eastern Africa are expected to be severely affected by climate change, with increased variability and warmer temperatures of greatest concern, resulting in crop yield declines for these areas. Another study estimates that an increase in temperature of $5^{\circ} \mathrm{C}$ in Eastern Africa may lead to a production decline of nearly 20 percent by the 2090s (USAID, 2012).

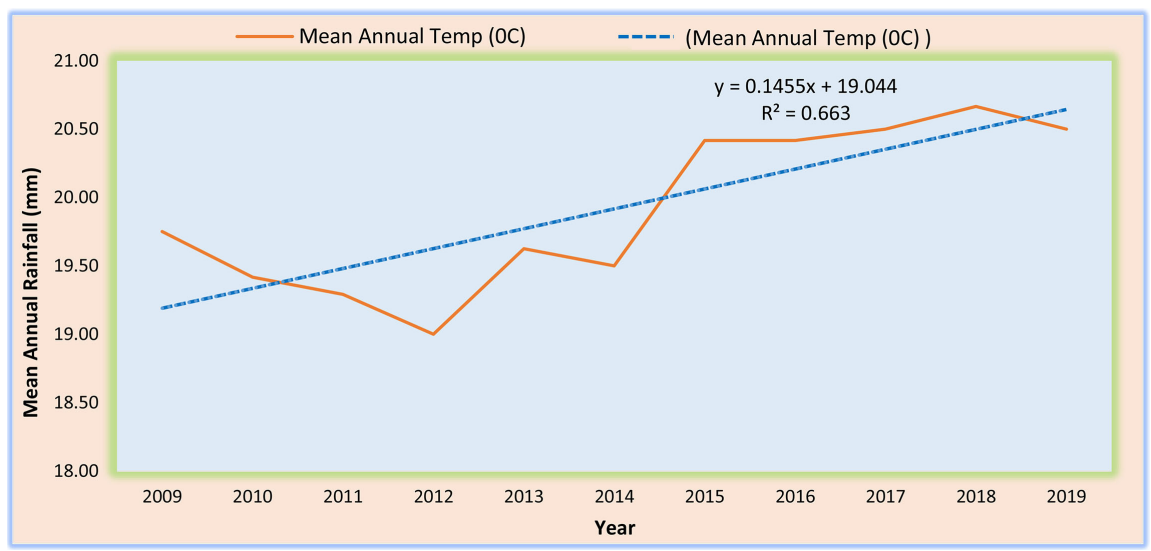

Figure 4. The Trend of Temperature at Burigi-Chato National Park from 2009-2019. Source: World Weather Online. 
The increasing temperature in the study area, also warns about the probability of future proliferation of a variety of invasive species colonizing many places of our protected areas, thereby worsening the suitability of habitats which wildlife species depend on. Essentially, the management of such biological invasion needs to be considered from the pathways point of view before their establishment, otherwise it will allow unnecessary cost and time implications to the park authority.

The highest mean annual temperature in the study area for a period of eleven years (2009-2019) was recorded to be $20.67^{\circ} \mathrm{C}$ in 2018 , this temperature is sufficient for the growth of Tegetes minuta in the park. Some studies have reported on the impacts of temperature on the spread of invasive species. For example, it was observed that the Tagetes minuta is propagated by seeds, which germinate over a period of 48 hours; most seeds germinate temperature between $20^{\circ} \mathrm{C}$ and $30^{\circ} \mathrm{C}$ (optimal $25^{\circ} \mathrm{C}$ ), with such temperature, germination of fresh seed may be as high as $95 \%$. At $36^{\circ} \mathrm{C}$, the thermo-inhibited proteins may result in the prevention of radical emergence at unfavourable temperatures (Holm et al., 1997).

Other possible effects of invasive plant species due to climate change may include: Longer growing season, thus increasing seed production and biomass; higher environmental temperatures improve plants' fertility resulting in increased population sizes (Marambe and Amarasinghe, 2002) and increased fruit and seed set due to enhanced activity of insect pollinators' activity (Marambe et al., 2009).

Increasing seasonality and marked wet and dry cycles therefore, benefitting aquatic invasive alien plants where fluctuations of water levels help expansion of the free-floating invasive species such as Eichhornia crassipes (Silva and Kurukulasuriya, 2010) that would likely to benefit from rising temperatures, and prolonged droughts supporting enhanced insect pest incidence (Wijesekara, 2010).

Other possible effects include higher $\mathrm{CO}_{2}$ levels-supporting the prevalence of C3 invasive species that are reported from Sri Lanka such as Mimosa pigra (Marambe et al., 2009); and changes in atmospheric circulation that affects the dispersion pathways of invasive plant species making warmer-water alien species become more abundant where established and helping their expansion (Marambe et al., 2009).

\subsection{Pathways of Plant Invasion}

An invasive plant can either be exotic (a plant living outside its native distribution range) or native to the area (Bernard, 2017). Invasion process of exotic invasive plants comprises of three stages namely; introduction from a donor region (whether intentional or accidentally), establishment in the recipient region (plants have chances of surviving but not spreading); spread (through naturalization) and invasion through a range expansion in the recipient region (Bernard, 2017; Simberloff, 2013). The pathways can be natural or man-made. Natural pathways (i.e., those not aided by humans) include for example wind and other 
forms of natural dispersal that can bring species to a new habitat. $\mathrm{Hu}$ man-induced activities are characteristically of two types which are intentional, or unintentional(USDA, No Date).

Another study (Lockwood et al., 2013) revealed that biological invasion is a process, which has been realized to pass through five stages or pathways namely; transport, introduction, establishment, spread and impact. In the cause of transport, invasive species can experience two scenarios, death or remain in captivity and may be introduced in a new area. When introduced, the invasive plant has the probability of failure or establish. Being established, it can remain local or spread. When spreading, it will have impacts, which can be low or high depending on the magnitude of the impact as perceived by people (Lockwood et al., 2013).

Alien species may arrive and enter a new region through three broad mechanisms: importation of a commodity, arrival of a transport vector, or spread from a neighbouring region. Pathways for invasive alien species are broadly categorized into three means, those related to transport of a commodity, related to a transport vector and those related to natural spread from a neighbouring region.

One of such pathways is release in nature (the intentional introduction of live invasive species for the purpose of human use in the natural environment, e.g. for fishing or hunting in the wild). Escape-the movement of (potentially) invasive alien species from confinement, e.g. from agriculture into the natural environment. The third one is transport-Contaminant referring to the unintentional movement of live organisms as contaminants of a commodity that is intentionally transferred through international trade. This may include seeds, other products of agriculture, forestry to mention but a few.

Those pathways related to a transport vector include the transport-stowaway. This refers to the moving of live organisms attached to transporting vessels and associated equipment and media, for example, various transportations, boats and other water vessels, fishing equipment etc. Stowaways of any other vehicles and equipment for human activities, such as waste dispersal, recreational boating, tourism (e.g., tourists and their luggage) are also included under this pathway.

The pathways related to natural spread from a neighbouring region include, corridor referring to movement of invasive species into a new region following the construction of transport infrastructures in whose absence spread would not have been possible. Such trans-biogeographical corridors include, for example, international canals (connecting river catchments and lakes or seas). Another pathway is unaided, which refers to the secondary natural dispersal of invasive alien species that have been introduced by means of any of the foregoing pathways.

The means by which these species have moved around the globe varies by taxonomic group, by geographic region, and over time. The bulk water (Ruiz et al., 1997) seems to be the single largest source of unintentional transfers of 
aquatic nonindigenous species throughout the world. While the major pathways of introductions of invasive species are now well recognized, there is not yet any comprehensive understanding of the many and varied routes by which introductions occur (D'Antonio et al., 2001). In East Africa, Tegetes minuta is abundant following fires or other clearing operations (CABI International, 2019).

During this study, it was observed at different locations that Tegetes minuta prefer growing near the road and places where previously were used for settlements. Disturbances of the study area as a result of roads construction, campsites establishment in the park and high chances of release of invasive plant species due to encroachment for fishing at Lake Burigi and livestock grazing (especially in the past) suggest high probability of the presence of invasive species in the study area.

Among other locations, Tegetes minuta was recorded at Birigi one camp (close to Lake Burigi), previously used for tourist hunting and "Msitu wa Tembo" (few kilometres from Nyungwe entrance gate) which have been used by wildlife rangers during their field patrols. Another disturbance could be caused by fumes originating from vehicles that frequently move in the park, which not only release $\mathrm{CO}_{2}$ fumes but also may act as pathways for releasing the weed in the area (unintentional).

The observed plants (Rengasamy et al., 2013) reached maturity rapidly and produced large quantities of seed that were easily transported by different methods such as vehicles, animals, water and came under the category of weeds due to the adaptation in absorbing food and water effectively under stress conditions.

It was observed that since Burigi-Chato is a protected area with a variety of wild animals, there is high probability of animals and birds being pathways of the Marigold (Tegetes minuta) seeds. Apart from scholarly findings reporting on encroachment of local communities for grazing in the study area, there was observed a dog (which either used to accompany pastoralists or fishermen who poach at Lake Burigi) frequently coming at Burigi one camp. Such domesticated animals could also be agents of the weed spread in the study area.

One study (SFGATE, 2018) found that seeds of Tegetes minuta may be blown by wind, carried by small animals, birds or can be transported away by rain. In areas where Tegetes minuta is cultivated, man can also contribute to the spread of the species.

\subsection{Factors Determine the Success of an Invasive Plant Species}

Climate: All species are adapted to a particular climatic range where temperature and rainfall (amount and distribution) play a significant role in tropical areas. It is possible to find similar regions of climate in different parts of the earth (biomes) (Medawatte et al., 2008). Microclimate: Habitats differ in their features such as light intensity, vegetation cover, wind, drainage and other edaphic factors and those can influence survival of a species in a specific habitat (Zhang et 
al., 2006).

Site and land use Patterns. Especially for plants, site-specific variables like edaphic properties play a key role in determining establishment and survival of a species in any particular area (Sheng and Bao, 2006). Species characteristics. Every species is genetically adapted to thrive on a set of specific environmental conditions. The genetic makeup defines its capacity to grow, to resist pests or predators, to resist diseases, and reproductive fecundity. Invasive species exhibit a wide genetic pool, which enhances their invasive potential (Sheng and Bao, 2006).

\subsection{Characteristics of Invasive Plant Species}

Invasive species exhibit a particular ecological profile rather than a biological profile. A species' traits determine their success or failure in the transition between different stages of the invasion process (Ratnayake, 2014). Invasive plant species possesses characteristics that make them especially suited for colonizing new ecosystems and those allow them to out-compete native plants for resources. Hence, successes of the control methods are impeded by vegetative, reproductive, life history, biochemical, genetic and ecological characteristic of invasive plant species (Ratnayake, 2014).

A combination of the characteristics of invasive plant species include: Biochemical and genetic characters (i.e. allelopathy), Vegetative and growth characters (Ratnayake, 2014); reproductive characteristics (species with multiple reproductive strategies, long or extended flowering and fruiting periods, production of large quantities of seeds or offspring, short life cycle, early maturity, high initial capacity of germination, efficient seed dispersal mechanism and long seed dormancy and staggered germination) (Witkowski \& Wilson, 2001; Sakai et al., 2001; Ratnayake, 2014); ecological characters; tolerance characters and seed dispersal (Ratnayake, 2014).

Some characteristic features of invasive plant species are: their rapidly growth and early maturity; many species are capable of vegetative reproduction via stolon, rooting at the tips of stem and root fragments; they are highly adapted to wind and insect pollination; their seeds get widely dispersed by winds, water, birds and other means, enabling them to colonize in new areas at distances far from their original home; they often have a different phenology for leafing to dormant stages that provide better opportunities to take nutrients from soil; and they usually are not attacked by parasites, diseases, herbivores, etc. in the newly introduced area. Attributes and categories to classify a plant species as invasive are given below (Table 3 ).

\subsection{Tagetes minuta and Its Ecological Impacts}

Tagetes minuta is a member of the Genus Tagetes classified under Asteraceae family (formerly, Compositae). The genus Tagetes is composed of about 56 species, out of which 27 are annual and 29 perennial species (Soule, 1996). 
Table 3. Attributes and categories to classify a plant species as invasive based on the threat it offers in a particular biogeographical region.

\begin{tabular}{|c|c|}
\hline Attributes & Categories \\
\hline Origin & $\begin{array}{l}\text { - taxa that evolved in the region, or reached it from another area wherethey are } \\
\text { native without human interference (native) } \\
\text { - taxa which owe their presencein the region to contemporary human activity } \\
\text { (non-native) }\end{array}$ \\
\hline $\begin{array}{l}\text { Natural } \\
\text { regeneration } \\
\text { potential }\end{array}$ & $\begin{array}{l}\text { - taxa that occur only temporarily in the area, and are not ableto persist for a long } \\
\text { time without human assistance } \\
\text { - form sustainable populations without human interference, but do not necessarily } \\
\text { spread }\end{array}$ \\
\hline Habitat type & $\begin{array}{l}\text { - do not establish in natural (undisturbed) ecosystems, spreading preferable over } \\
\text { disturbed areas } \\
\text { - form sustainable populations without human interference and spread over natural } \\
\text { (undisturbed) ecosystems }\end{array}$ \\
\hline Dominance & $\begin{array}{l}\text { - do not inhibit native species regeneration and growth } \\
\text { - changethe composition or structure of thenative plant community, } \\
\text { inhibiting or suppressing the regeneration of native species }\end{array}$ \\
\hline
\end{tabular}

Adopted from Durigan et al. (2003).

Tagetes minuta originated in South America, and has been deliberately distributed across the tropics, subtropics and several temperate countries as an ornamental, medicinal or perfume plant as well as accidentally as a weed (Stadler et al., 1998).

Tegetes minuta was observed to be abundant in some locations within the park (Figure 5). The plant lasts for 4 to 6 months depending upon the time of sowing, crop practice followed and the prevalent climatic conditions (CABI International, 2019). In another study, it was reported that T. minuta was originally restricted to the higher altitudes, but has since spread to lower altitudes as a result of increasing agricultural activities (Stadler et al., 1998).

A number of studies have been conducted to investigate the negative ecological consequences of invasive species on ecosystem processes (Levine et al., 2003; Dukes and Mooney, 2004). Invasive weeds have been reported to possess the ability of changing plant community composition by suppressing the abundance of indigenous species (Vasquez et al., 2008).

Biological invasions (Millennium Ecosystem Assessment, 2005) are one of the main causes of declines of biodiversity, which translates into reduced ecosystem services worldwide. Synergistic interactions between invasive plant species and other elements of global change (Pyšek \& David, 2010) make it difficult to assign a rank to specific causes of biodiversity decline; however, invasions are regarded as a fundamental driver of ecosystem degradation in many parts of the world.

Among other ecological impacts, invasive species affect the functioning of ecosystems by changing the availability of resources and the disturbance regimes of invaded ecosystems (Richardson et al., 2000) impacts of invasions on soil processes (Liao et al., 2008); impacts on native species richness (Gaertner et al., 2009), and competition from aliens with native plants (Vila et al., 2004). 


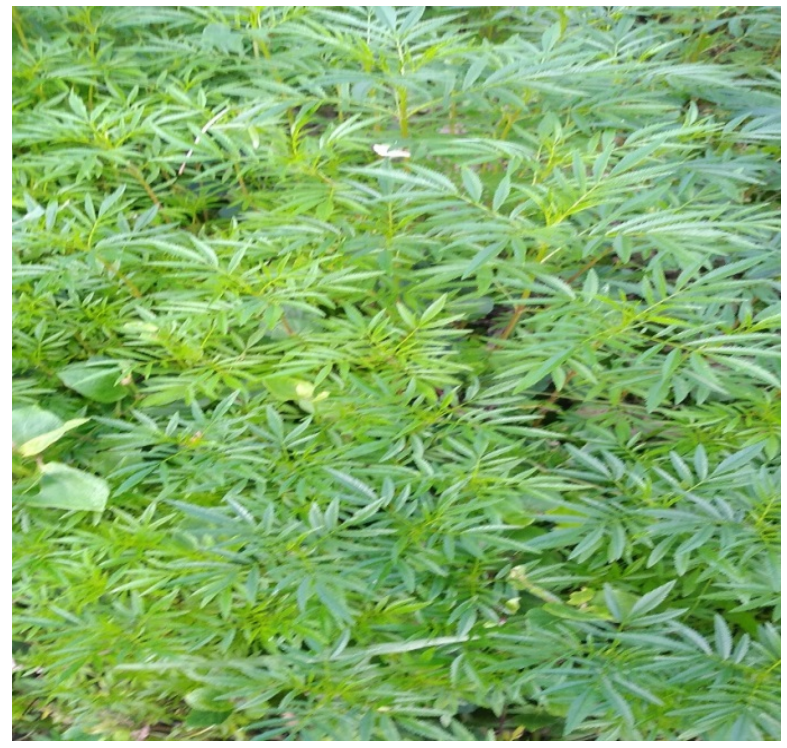

Figure 5. Booming of the Tegetes minuta, an invasive plant species in Burgi-Chato National Park as observed at "Msitu wa Tembo" area, few kilometres from Nyungwe gate.

\subsection{Adverse Effects of Tegetes minuta on Agricultural Crops}

Seeds (Holm et al., 1997) do not require light for germination; however, they respond to it very positively, so that germination only occurs from seeds near the soil surface and most seedlings emerge from soil depths of less than $6 \mathrm{~mm}$.

Tagetes minuta may leave allelopathic residues in soil. The roots exude a polyacetylene derivative which delays germination and reduces the yield of crops grown in soil previously infested with the species (Meissner et al., 1986). Tegetes minuta oil possesses phytotoxicity (a delay of seed germination, inhibition of plant growth) toward test weeds. Radicle growth was affected more compared to the plumule. The effect of Tegetes minuta oil varied from species to species with maximum allelopathic inhibition of Amaranthus viridis and Amaranthus tricolor (Arora, 2017).

Tegetes minuta is a fast-growing annual weed which competes with crops and interferes with their management or harvest. It has been reported as a weed of 19 crops in 35 countries (Holm et al., 1997). Its presence in a crop may also lead to skin irritation to agricultural workers (CABI International, 2019). Teteges minuta is a significant crop seed contaminant in East Africa (Holm et al., 1997).

The weed is an alternative host to the bean fungus Ascochyta phaseolorum as revealed in Australia (Holm et al., 1997). This invasive plant may be also found to leave allelopathic residues in soil (Meissner et al., 1986). The roots exude a polyacetylene derivative which delays germination and reduces the yield of crops grown in soil previously infested with the species (CABI International, 2019).

\subsection{Management of Invasive Plant Species}

Effective management of invasive plant species is clearly a priority for biological 
conservation worldwide. Manual uprooting, burning and controlling through uses and weeding, hoeing and ploughing were applied as controlling measures and plantation of fodder trees and grasses was used as controlling and preventive measure. Multiple methods were often applied for controlling, however almost were controlling focused for Ageratum conyzoides in Nepal.

Effective management of biological invasion should follow three main steps from prevention; early detection and eradication; and control backed up by integrated management. Prevention is the best form of invasive species management (Rejmanek, 2005). If prevention is no longer possible, it is best to treat infestations when they are small to prevent them from establishing. Controlling the weed before seeds will reduce future problems. Control is generally best applied to the least infested areas before dense infestations are tackled (Rejmanek, 2005).

A number of integral prevention and control practices methods have been applied to prevent the spread of invasive plant species in the US. Such methods include (California Invasive Plant Council, 2012) provision of prevention training to staff and contractors prior to starting work; scheduling activities to minimize potential for introduction and spread of invasive plants; surveying for invasive plants and evaluate risks before activities begin; Clean clothing, footwear and gear before leaving infested areas; and lastly, after activities, monitor worksites for invasive plants using monitoring plans.

Other measures (California Invasive Plant Council, 2012) include designation of waste disposal areas for invasive plant materials; planning travel routes to avoid areas infested with invasive plants; cleaning tools, equipment, vehicles and animals before transporting materials and before entering and leaving worksites; prepare worksites to limit the introduction and spread of invasive plants; and minimize soil and vegetation disturbance).

Tagetes minuta like other invasive plant species particularly, can be controlled by a variety of methods such as cultural control, mechanical control, and chemical control. Using cultural control (CABI International, 2019), Tegetes minuta can be easily uprooted or removed by hand or mechanical cultivation. However, this should be done at early stages of plant growth before the flowers form to prevent the return of viable seeds to the soil. Using mechanical control (CABI International, 2019), tillage and hand pulling are very effective in controlling the plant in agricultural fields and in cultivation processes. Nonetheless, agricultural machines should be cleaned to prevent seed dispersal among fields.

Tagetes minuta revealed susceptibility to acifluorfen, ametryne, bentazon, bifenox, bromacil, cyanazine, dicamba, diphenamid, diquat, diuron, 2,4-D, glyphosate, imazaquin, linuron, metribuzin, molinate, oxadiazon, oxyfluorfen, paraquat and simazine, the study revealed during in screening trials in Brazil, (Lorenzi, 1986). Current Australian registrations for the control of Tagetes minuta include 2,4-D, MCPA, norflurazon, prometryn, pendimethalin, atrazine, 2,4-D + picloram, linuron, and bromacil + diuron (Hamilton, 1997). At the mo- 
ment, no biological control has been attempted against Tagetes minuta (CABI International, 2019).

Generally, in the course of implementing efforts to control biological invasion, such invasive species and pathways are to be identified and prioritized; priority species need are controlled or eradicated, and measures are put in place to manage pathways to prevent their introduction and establishment. Thus, with relation to pathways, the Target contains three elements: to identify pathways; to prioritize pathways; and to manage pathways (UNEP \& CBD, 2014). Strategies used to control invasive species (Ratnayake, 2014) include keeping potential invaders out, eradicating potential invaders soon after invasion, biological control, chemical control, and mechanical control.

\subsection{Rare Plant Species Identified in Burigi-Chato National Park}

Six rare plant species were identified and recorded during the study. The rare species were found to be the most important due to its scantiness and great medicinal and industrial value by humans, which if not controlled, will put the rare plants in jeopardy of extinction in the future. Of the identified rare species, two of them were considered the most important medicinal pressures from human. The plant species were the Knob-wood tree or Kokwaro (Zanthoxylum usambarense) and Large-leaved common gardenia (Gardenia ternifolia).

Most Zanthoxylum species produce pungent alkamides derived from polyunsaturated carboxylic acids, stored in the pericarp. The plants have been used to treat backache, pneumonia, malaria, and rheumatism by local Maasai people of Tanzania. The pharmaceutical industry has captured the use of this tree by exuding/oozing materials such as methanol and aqueous extracts to produce anti-malaria, and canthin-6-one have shown effective as an anti-fungal drug.

\subsection{Medicinal Value of Zanthoxylum usambarense}

Zanthoxylum usambarense (Figure 6) is grouped under the family Rutaceae (Citrus family). The genus Zanthoxylum comprises about 549 species distributed worldwide mainly in tropical and temperate regions (Global Biodiversity Information Facility, 2010). Zanthoxylum usambarense has traditionally been used for the treatment of malaria, upper respiratory tract infections, cough, rheumatism, tooth decay and sore gums in Kenya and other African countries (Ozkan et al., 2012). The present findings demonstrated that Zanthoxylum usambarense could be a potential source for new cytotoxic compounds for possible anticancer drug development (Ozkan et al., 2012).

The dichloromethane fraction of the roots and the bark of Zanthoxylum usambarense were proved to have medicinal significance in inhibition of different types of fungi and also against the housefly (Musca domestica). The test also showed positive results in insecticidal activities (Van Puyvelde \& Bosselaers, 2002). Traditionally, some tribes in Tanzania including Wakara and Wajita use dried powder of the $Z$. usambarense barks to treat flu, headache and stomach pains. 


\subsection{Medicinal Value of Gardenia ternifolia}

Gardenia (Figure 7) is classified under family Rubiaceae. Extracts of anthocyanins and organic acids from Gadenia ternifolia (Ngbolua et al., 2015) were reported to be the major anti-sickling agents used in Congolese folk medicine for the management of microbial infections, especially those due to bacteria are recurrent pathologies of the Sickle Cell Disease (SCD).

Traditional medicine (Ngbolua et al., 2015) continues to play a very significant role in the medical primary health care implementation in developing countries. Administration of the aqueous leaves extract of Gardenia ternifolia plant (ALEGTP) offered more improvement on preventing the severity of damage to the liver by carbon tetrachloride $\left(\mathrm{CCl}_{4}\right)$, a toxic chemicals, which has ability of causing liver damage in mammals as it was revealed as a result of a test conducted using rats (Yunana \& Dahiru, 2015).

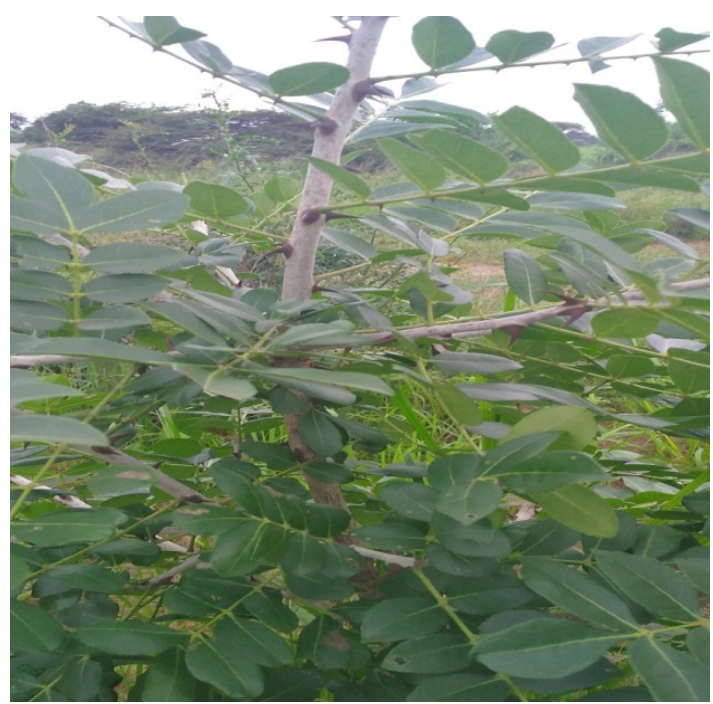

Figure 6. Zanthoxylum usambarense plant-leaves and young twigs.

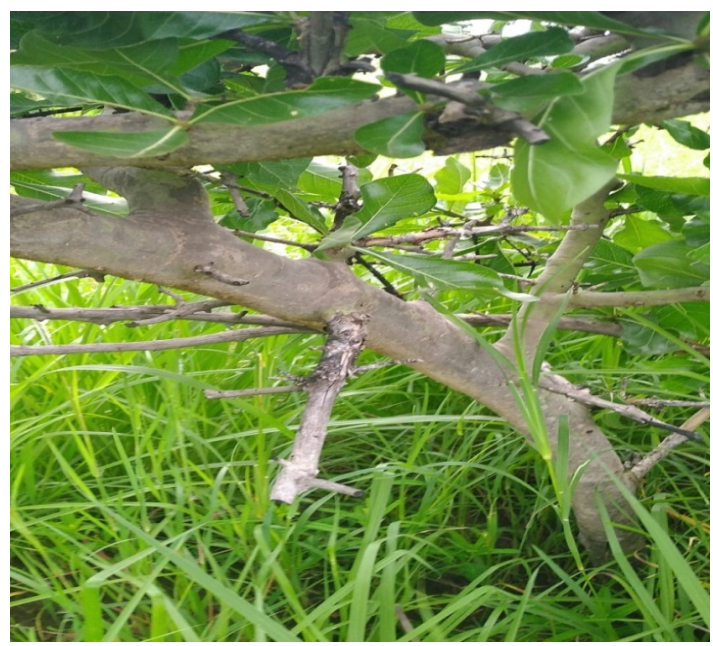

Figure 7. Gardenia ternifolia plant. 


\subsection{Management of Rare Plant Species}

Species are considered rare if their area of occupancy or their numbers are small when compared to the other species that are taxonomically or ecologically comparable (Flather \& Sieg, 2007). In another study, a species is considered to be "rare" if it exhibits any one of the following attributes: The species is naturally occurring in a narrow geographical area; and/or occupies only one or a few specialized habitats and forms only small population(s) in its range (Isik, 2011).

Many rare and/or endemic species reveal one or more of the following aspects, which make them especially prone to extinction: If a species inhabits a narrow (and single) geographical range; has one or a few populations; has small population size and little genetic variability; is over-exploited by people; its population sizes are declining; has low reproductive potential; the need for specialized ecological niches; and that its growth needs steady and almost constant environments (Isik, 2011).

Species that experience any of the above attributes must be given priority, monitored and managed carefully in an effort to promote genetic conservation (Isik, 2011).

In conservation biology, a species' rarity is defined most based on its distribution and abundance (Gaston, 1994). Species considered threatened with extinction will more than likely also be considered rare (Gaston, 1994). The IUCN Red List of Threatened Species is based on risk of extinction criteria (IUCN, 2001, 2005).

The main criteria used in assessing extinction risk include: population size; geographic range (both extent of occurrence and area of occupancy) and; population size trajectory. Other assessment criteria are: degraded habitat quality, levels of exploitation, and the effects of introduced taxa, hybridization, pathogens, pollutants, competitors, or parasites (IUCN, 2001).

Conservationists are highly concerned with rare species due to that those which are rare will have a greater extinction risk than those that are common (Johnson, 1998; Matthies et al., 2004). Small populations are more likely to be impacted by chance demographic and environmental events, such as failure to reproduce, diseases, floods, and fires (Boyce, 1992).

Species rarity can be contributed by two broad categories of natural or intrinsic causes defined by a species' inherent biological or ecological characteristics; and anthropogenic or extrinsic causes defined by harmful human activities that have resulted in limited distribution and abundance, independent of their biology (Partel et al., 2005). Habitat loss and habitat degradation have been revealed as the major anthropogenic factors that increase species rarity (Wilcove et al. 2000).

Management of rare plants requires that populations are monitored. Monitoring generally includes counts or estimates of population size, and often includes demographic data that provide detailed information with which to manage populations and meta-populations (Bevill \& Louda, 1999). Due to small 
populations and scattering of rare plants, a multistage sampling approach that allows efficient and effective monitoring has been developed (Glitzenstein et al., 2001). Management plans can include habitat restoration and species re-introduction. Also habitat prediction models can be used to identify suitable habitats for species re-introduction or increase efficiency of rare plant survey on large sites (Imm et al., 2001).

\section{Conclusion}

A total of 102 plant species within the sampled area. Out of 102 species so identified, two (2) species which are Tegetes minuta a member of family Asteraceae and Argemone mexicana belonging to family Papaveraceae were observed to be dangerous invasive species. The area was also recorded to have six (6) rare species, which suggests the area to be potential for conservation in western part of the country. The rare species were identified as Faidherbia albida, Harrisonia abyssinica, Zanthoxylum usambarense, Anona senegalensis, Pappea capensis, and, Gardenia ternifolia. Findings indicated that the study area receives an average of $964.36 \mathrm{~mm}$ per year. The highest peak of rainfall was recorded in 1951 with almost $1600 \mathrm{~mm}$. Such rainfall is sufficient to support the growth of invasive species. Soil nutrients and pressures that cause disturbance of the area have contributed to the spread of Tegetes minuta. The trend of rainfall, however, indicated that many recorded years had rainfall below average, suggesting that climate change exists in the study area. On the other hand, the temperature was found to increase from year to year. There was also no statistical significance difference between the mean annual temperature and maximum annual wind speed. A number of disturbances, meteorological and edaphic factors were found to contribute to the growth of invasive species. In combating invasive species, urgent measures need to be taken before they are left to thrive in the park to avoid destruction of the habitat suitability and eventually incurring unnecessary expenses and time in combating them. Elimination of invasive plant species from the park is thus, vital before their widespread to avoid competition with native plant species, cost and time. The documented rare plant species, in particular those with pharmaceutical and industrial values need to be conserved with special attention to ensure their survival.

\section{Recommendations}

Based on the findings of this study, it was recommended that:

- Prominent (eye-catching) trees in camp sites should be labelled with scientific, English (and vernacular) names for fascinating visitors and researchers.

- Ecological assessment within the park should be conducted regularly to maintain the ecological health by eliminating invasive plant species and protecting biological diversity such as rare plant species their extinction.

- Human-induced activities such as grazing, deforestation/forest degradation etc. should be prevented through regular field patrols and public awareness 
programs to ensure existence of plants in the area.

- Nature trails should be designed for tourists interested in walking safaris to make easy identification and viewing smaller plant species.

- Since this study was conducted during wet season, it is suggested that another similar study be conducted during dry season to investigate the performance of plants, as the way of making comparison of the capacity of such plants in adapting different changes of the climate.

- Collaboration between the park authority and training institutions is essential for undertaking more studies to discover other unknowns as the way of improving conservation of natural resources in the area.

\section{Conflicts of Interest}

The authors declare no conflicts of interest regarding the publication of this paper.

\section{References}

Arora, K. (2017). Allelopathic Impact of Essential Oil of Tagetes minuta on Common Agricultural and Wasteland Weeds. Innovare Journal of Agricultural Sciences, 5, 1-4.

Assistant Conservation Commissioner (2019). Burigi-Chato National Park.

Bernard, N. I. (2017). Ecological Effects of Selected Invasive Plants and Their Nature Based Management Approaches. Arusha: The Nelson Mandela African Institution of Science and Technology. http://dspace.nm-aist.ac.tz/handle/123456789/267

Bevill, R. L., \& Louda, S. M. (1999). Comparison of Related Rare and Common Species in the Study of Plant Rarity. Conservation Biology, 13, 493-498.

https://doi.org/10.1046/j.1523-1739.1999.97369.x

Boyce, M. S. (1992). Population Viability Analysis. Annual Review of Ecology and Systematics, 23, 481-506. https://doi.org/10.1146/annurev.es.23.110192.002405

Bradley, B. A., Blumenthal, D. D., Wilcove, D. S., \& Ziska, L. H. (2010). Predicting Plant Invasions in an Era of Global Change. Trends in Ecology and Evolution, 25, 310-318. https://doi.org/10.1016/j.tree.2009.12.003

CABI International (2019). Invasive Species Compendium. https://www.cabi.org/isc/datasheet/52642

California Invasive Plant Council (2012). Preventing the Spread of Invasive Plants: Best Management Practices for Transportation and Utility Corridors. http://www.cal-ipc.org

CBD [Convention on Biological Diversity] News (2001). Convention on Biological Diversity. https://www.cbd.int/doc/newsletters/news-letter-01-03-2001.pdf

CBD [Convention on Biological Diversity] (1992). Convention on Biological Diversity. United Nations: Rio Earth Summit.

Chen, B., Liao, H., Chen, W., Wei, H., \& Peng, S. (2017). Role of Allelopathy in Plant Invasion and Control of Invasive Plants. Allelopathy Journal, 41, 155-166. https://doi.org/10.26651/2017-41-2-1092

D’Antonio, C., Levine, J., \& Thomsen, M. (2001). Fire, Plant Invasions, and Global Changes. In H. A. Mooney, \& R. J. Hobbs (Eds.), Invasive Species in a Changing World (pp. 65-93). Washington DC: Island Press. 
Dharani, N. (2006). Field Guide to Common Trees \& Shrubs of East Africa. Cape Town: Struik Publishers.

Dix, M. E., Buford, M., Slavicek, J., Solomon, A. M., \& Conard, S. G. (2009). Invasive Species and Disturbances: Current and Future Roles of Forest Service Research and Development. A Dynamic Invasive Species Research Vision: Opportunities and Priorities 2009-29.

Dukes, J. S., \& Mooney, H. A. (1999). Does Global Change Increase the Success of Biological Invaders? Trends in Ecology and Evolution, 14, 135-139. https://doi.org/10.1016/S0169-5347(98)01554-7

Dukes, J. S., \& Mooney, H. A. (2004). Disruption of Ecosystem Processes in Western North America by Invasive Species. Revista Chilena de Historia Natural, 77, 411-437. https://doi.org/10.4067/S0716-078X2004000300003

Durigan, G., Ivanauskas, N. M., Maria, J. B., Zakia, M. J. B., \& de Abreu, R. C. R. (2003). Control of Invasive Plants: Ecological and Socioeconomic Criteria for the Decision Making Process. Natureza \& Conservação, 11, 23-30. https://doi.org/10.4322/natcon.2013.003

FAO (2010). Analysis of Climate Change and Variability Risks in the Smallholder Sector: Case Studies of the Laikipia and Narok Districts Representing Major Agro-Ecological Zones in Kenya. In O. O. Gordon, A. Jaspat, \& S. Charles (Eds.), Environmental and Natural Resources Working Paper (Vol. 41). Department of Resource Surveys and Remote Sensing (DRSRS) in Collaboration with the Food and Agriculture Organization of the United Nations, Rome, Italy.

Flather, C. H., \& Sieg, C. H. (2007). Chapter 3. Species Rarity: Definition, Causes, and Classification. In Conservation of Rare or Little-Known Species: Biological, Social, and Economic Considerations (pp. 40-66). Washington DC: Island Press. https://www.fs.fed.us/rm/pubs_other/rmrs_2007_flather_c002.pdf

Gaertner, M., Breeyen, A. D., Hui, C., \& Richardson, D. M. (2009). Impacts of Alien Plant Invasions on Species Richness in Mediterranean-Type Ecosystems: A Meta-Analysis. Progress in Physical Geography, 33, 319-338.

https://doi.org/10.1177/0309133309341607

Gaston, K. J. (1994). Rarity. London: Chapman and Hall. https://doi.org/10.1007/978-94-011-0701-3

Glitzenstein, J. S., Streng, D. R., \& Wade, D. D. (2001). Starting New Populations of Longleaf Pine Ground-Layer Plants in the Outer Coastal Plain of South Carolina, USA. Natural Areas Journal, 21, 89-110.

Global Biodiversity Information Facility (2010). Biodiversity Occurrence Data. GBIF Data Portal. http://data.gbif.org/species

Hamilton, K. (1997). PESKEM-USES-PESTS: The Australian Directory of Registered Pesticides and their Uses (15th ed.). Gatton: University of Queensland.

Holm, L. G., Doll, J., Holm, E., Pancho, J. V., \& Herberger, J. P. (1997). World Weeds: Natural Histories and Distribution. New York: John Wiley \& Sons Inc.

Imm, D. W., Shealy Jr., H. E., McLead, K. W., \& Collins, B. (2001). Rare Plants of South-Eastern Hardwood Forests and the Role of Predictive Modeling. Natural Areas Journal, 21, 36-49.

Isik, K. (2011). Rare and Endemic Species: Why Are They Prone to Extinction? Turkish Journal of Botany, 35, 411-417.

IUCN [International Union for the Conservation of Nature] (2001). IUCN Red List Categories and Criteria: Version 3.1 IUCN Species Survival Commission. Gland and 
Cambridge: IUCN.

https://portals.iucn.org/library/sites/library/files/documents/RL-2001-001.pdf

IUCN [International Union for the Conservation of Nature] (2005). Guidelines for Using the IUCN Red List Categories and Criteria. Standards and Petitions Subcommittee of the IUCN Red List Programme Committee.

Jambiya, G., Milledge, S. A. H., \& Mtango, N. (2007). "Night Time Spinach": Conservation and Livelihood Implications of Wild Meat Use in Refugee Situations in NorthWestern Tanzania. Dar es Salaam: TRAFFIC East/Southern Africa.

Johnson, C. N. (1998). Species Extinction and the Relationship between Distribution and Abundance. Nature, 394, 272-274. https://doi.org/10.1038/28385

Kiss (1977). Tanzania Country File. http://www.fao.org/docrep/005/T0473E/T0473E09.htm

Kulekana, J. J. (2004). Levels of Nitrate and Phosphate in Some Satellite Lakes within the Lake Victoria Basin, Tanzania. Tanzania Journal of Science, 30, 1-10. https://doi.org/10.4314/tjs.v30i1.18382

Levine, J. M., Vila, M., Antonio, C. M., Dukes, J. S., Grigulis, K., \& Lavorel, S. (2003). Mechanisms Underlying the Impacts of Exotic Plant Invasions. Proceedings of the Royal Society of London B: Biological Sciences, 270, 775-781. https://doi.org/10.1098/rspb.2003.2327

Liao, C., Peng, R. Luo, Y., Zhou, X., Wu, X., Fang, C., Chen, J., \& Li, B. (2008). Altered Ecosystem Carbon and Nitrogen Cycles by Plant Invasion: A Meta-Analysis. New Phytologist, 177, 706-714. https://doi.org/10.1111/j.1469-8137.2007.02290.x

Lockwood, J. L., Hoopes, M. F., \& Marchetti, M. P. (2013). Invasion Ecology (2nd ed.). Hoboken, NJ: John Wiley \& Sons, Ltd.

Lorenzi, H. (1986). Manual de Identificacao e Controle de Plantas Daninhas. Sao Paulo: Nova Idessa.

Mangold, J. (2018). Plant Identification Basics. Bozeman, MT: Montana State University, Agriculture and Natural Resources (Weeds).

https://store.msuextension.org/publications/AgandNaturalResources/MT201304AG.pdf

Marambe, B., \& Amarasinghe, L. (2002). Propanil-Resistant Barnyardgrass (Echinochloa crusgalli L. Beauv) in Sri Lanka: Seedling Growth under Different Temperatures and Control. Weed Biology and Management, 2, 194-199. https://doi.org/10.1046/j.1445-6664.2002.00068.x

Marambe, B., Wijesundera, S., \& Silva, P. (2009). Climate Change and Invasive Alien Species. In Global Climate Change and Its Impacts on Agriculture, Forestry and Water in the Tropics (pp. 97-113). Kandy. https://www.researchgate.net/publication/280302098

Masalu, F. I. (2008). Impact of Refugees on Wildlife Habitats and Populations in Burigi and Kimisi Game Reserves, Ngara District, Tanzania. http://suaire.suanet.ac.tz:8080/xmlui/bitstream/handle/123456789/373/FAUSTINE\%20 ILOBI\%20MASALU\%202008.pdf?sequence=1\%26isAllowed $=\mathrm{y}$

Masuki, K. F. G., \& Mbogoni, J. D. J. (2016). Agro-Ecological Zones of the Lake Zone, Tanzania.

https://www.researchgate.net/publication/299758267_AGRO-ECOLOGICAL_ZONES_ of_the_LAKE_ZONE_TANZANIA/link/5705017f08aef745f7172cfb/download

Matthies, D., Brauer, I., Maibom, W., \& Tscharntke, T. (2004). Population Size and the Risk of Local Extinction: Empirical Evidence from Rare Plants. Oikos, 105, 481-488. https://doi.org/10.1046/j.1445-6664.2002.00068.x 
McNeely, J. (2001). Invasive Species: A Costly Catastrophe for Native Biodiversity. IUCN Biodiversity Programme, Gland, Switzerland. Land Use and Water Resources Research, 2, 1-10.

Mduma, S. A. R., Sinclair, A. R. E., \& Hilborn, R. (1999). Food Regulates the Serengeti Wildebeest: A 40-Year Records. Journal of Animal Ecology, 68, 1101-1122. https://doi.org/10.1046/j.1365-2656.1999.00352.x

Medawatte, W. W. M. A. B., Tennakoon, K. U., Hulme, P. E., \& Gunatilleke, I. A. U. N. (2008). Spread of Caribbean Pine into the Grasslands of the Knuckles Range, Sri Lanka. In Proceedings of the National Symposium on Invasive Alien Species. Colombo.

Meissner, R., Nel, P. C., \& Beyers, E. A. (1986). Allelopathic Influence of Tagetes- and Bidens-Infested Soils on Seedling Growth of Certain Crop Species. South African Journal of Plant and Soil, 3, 176-180. https://doi.org/10.1080/02571862.1986.10634217

Millennium Ecosystem Assessment (2005). Ecosystems and Human Well-Being: Biodiversity Synthesis. Washington DC: World Resources Institute.

MNRT [Ministry of Natural Resources and Tourism] (2005). Burigi, Biharamulo and Kimisi Game Reserves Management Plan, Kagera Region. Kagera/Kigoma Game Reserves Rehabilitation Project, Dar es Salaam: Wildlife Division, Ministry of Natural Resources and Tourism, United Republic of Tanzania.

Mutagwaba, S. J. (2010). Diversity and Distribution of A vifauna Resource: A Case of Lake Burigi Wetland, North Western Tanzania. https://pdfs.semanticscholar.org/809a/a9a74557fa57ee32725e7bcd385022bc11f0.pdf

Ngbolua, K. N., Tshibangu, D. S. T., Mpiana, P. T., Mihigo, S. O., Mavakala, B. K., Ashande, M. C., \& Muanyishay, L. C. (2015). Anti-Sickling and Antibacterial Activities of Some Extracts from Gardenia ternifolia subsp. Jovis-tonantis (Welw.) Verdc. (Rubiaceae) and Uapaca heudelotii Baill. (Phyllanthaceae). Journal of Advances in Medical and Pharmaceutical Sciences, 2, 10-19. https://doi.org/10.9734/JAMPS/2015/13427

Obiri, J. (2011). Invasive Plant Species and Their Disaster-Effects in Dry Tropical Forests and Rangelands of Kenya and Tanzania. JÀMBÁ: Journal of Disaster Risk Studies, 2, 151-158. https://doi.org/10.4102/jamba.v3i2.39

Oosterom, A. P., Ngailo, J. A., Kileo, R. O., Mbogoni, J. D. J., Msangi, A. S., Andriesse, W., \& van Kekem, A. J. (1999). Land Resources of Biharamulo District, Kagera Region Tanzania. Volume 2, Appendices. International Activity Report 75, Wageningen: Winand Staring Centre for lntegrated Land, Soil and Water Research.

Ozkan, M., Mutiso, P. B. C. et al. (2012). Zanthoxylum usambarense (Engl.) Kokwaro (Rutaceae) Extracts Inhibit the Growth of the Breast Cancer Cell Lines MDA-MB-231 and MCF-7, But Not the Brain Tumour Cell Line U251 in Vitro. Phytotherapy Research, 27, 787-790. https://doi.org/10.1002/ptr.4775

Partel, M., Kalamees, R., Reier, U., Tuvi, E., Roosaluste, E., Vellak, A., \& ZobeL, M. (2005). Grouping and Prioritization of Vascular Plant Species for Conservation: Combining Natural Rarity and Management Need. Biological Conservation, 123, 271-278. https://doi.org/10.1016/j.biocon.2004.11.014

Pyšek, P., \& David, R. (2010). Invasive Species, Environmental Change and Management, and Health. Annual Review of Environment and Resources, 35, 25-55. https://doi.org/10.1146/annurev-environ-033009-095548

Pysek, P., Richardson, D. M., \& Jarosík, V. (2006). Who Cites Who in the Invasion Zoo: Insights from an Analysis of the Most Highly Cited Papers in Invasion Ecology. Preslia, $78,437-468$.

Ratnayake, R. M. C. S. (2014). Why Plant Species become Invasive? Characters Related to 
Successful Biological Invasion. In Proceedings of the National Symposium on Invasive Alien Species (pp. 22-42). Colombo. https://www.researchgate.net/publication/273452847

Rejmanek, M. (2005). Invasive Plants: Approaches and Predictions. Austral Ecology, 25, 497-506. https://doi.org/10.1046/j.1442-9993.2000.01080.x

Rengasamy, P., Senthilkumar, M., \& Komalavalli, N. (2013). Impact of Vehicular Emission on Morphological Characteristics of NH-210 Road Side Flora. Indian Journal of Natural Sciences, 4, 1403-1414.

Richardson, D. M., Pysek, P., Rejmanek, M., Barbour, M. G., Panetta, F. D., \& West, C. J. (2000). Naturalization and Invasion of Alien Plants: Concepts and Definitions. Diversity and Distributions, 6, 93-107. https://doi.org/10.1046/j.1472-4642.2000.00083.x

Roodt, V. (2005). The Tourist Travel and Field Guide of the Serengeti National Park. Johannesburg: Papyrus Publications.

Ruiz, G. M., Carlton, J. T., Grosholz, E. D., \& Hines, A. H. (1997). Global Invasions of Marine and Estuarine Habitats by Non-Indigenous Species: Mechanisms, Extent, and Consequences. American Zoologist, 37, 621-632. https://doi.org/10.1093/icb/37.6.621

Runyon, J. B., Butler, J. L., MFriggens, M. M., Meyer, S. E., \& Sing, S. E. (2012). Invasive Species and Climate Change. USDA Forest Service, General Technical Report RMRS-GTR.

Sakai, A. K., Allendorf, F. W., Holt, J. S., Lodge, D. M., Molofsky, J., With, K. A., Baughman, S., Cabin, R. J., Cohen, J. E., Ellstrand, N. C., McCauley, D. E., O’Neil, P., Parker, I. M., Thompson, J. N., \& Weller, S. G. (2001). The Population Biology of Invasive Species. Annual Review of Ecology, Evolution, and Systematics, 32, 305-332. https://doi.org/10.1146/annurev.ecolsys.32.081501.114037

Scott, D. (2005). Global Environmental Change and Mountain Tourism. In S. Gössling, \& C. M. Hall (Eds.), Tourism and Global Environmental Change: Ecological, Economic, Social and Political Interrelationships (pp. xiii-227). New York: Routledge.

SFGATE (2018). How Do Marigolds Disperse Their Seeds? https://homeguides.sfgate.com/marigolds-disperse-seeds-76176.html

Sheng, Y. Y., \& Bao, T. X. (2006). Biological Characteristics of Alien Plants Successful Invasion, 17, 727-732. https://www.ncbi.nlm.nih.gov/pubmed/16836110

Silva, P., \& Kurukulasuriya, M. (2010). Climate Change and Livestock.

Simberloff, D. (2013). Invasive Species: What Everyone Needs to Know. New York: Oxford University Press.

Soule, J. A. (1996). Novel Annual and Perennial Tegetes. In J. Janick (Ed.), Progress in New Crops (pp. 546-551). Arlington, VA: ASAH Press.

Stadler, J., Mungai, G., \& Brandl, R. (1998). Weed Invasion in East Africa: Insights from Herbarium Records. African Journal of Ecology, 36, 15-22.

https://doi.org/10.1046/j.1365-2028.1998.115-89115.x

TANAPA [Tanzania National Parks] (2020). Presentation during World Wildlife Day, 3rd March 2020. Mweka: College of African Wildlife Management.

Terry, G. (2009). Climate Change and Gender Justice. Warwickshire, UK: Practical Action Publishing in Association with Oxfam GB.

UNEP [United Nations Environmental Programme] \& CBD (2014). Pathways of Introduction of Invasive Species, Their Prioritization and Management. In Subsidiary Body on Scientific, Technical and Technological Advice, Eighteenth Meeting. Montreal.

USAID [United States Agency International Development] (2012). Climate Change Adaptation in Tanzania. 
https://www.climatelinks.org/sites/default/files/asset/document/tanzania_adaptation_f act_sheet_jan2012.pdf

USDA [U.S. Department of Agriculture National] Invasive Species Information Center (No Date). Pathways. https://www.invasivespeciesinfo.gov/subject/pathways

Van Puyvelde, L., \& Bosselaers, J. (2002). Chemical Constituents and Biological Activities of Zanthoxylum usambarense. Phytotherapy Research, 16, 66-70.

https://www.researchgate.net/publication/11551210 https://doi.org/10.1002/ptr.849

Vasquez, E., Sheley, R., \& Svejcar, T. (2008). Creating Invasion Resistant Soils via Nitrogen Management. Invasive Plants Science and Management, 1, 304-314. https://doi.org/10.1614/IPSM-07-059.1

Vila, M., Williamson, M., \& Lonsdale, M. (2004). Competition Experiments on Alien Weeds with Crops: Lessons for Measuring Invasive Impact? Biological Invasions, 6, 59-69. https://link.springer.com/article/10.1023/B:BINV.0000010122.77024.8a https://doi.org/10.1023/B:BINV.0000010122.77024.8a

Wijesekara, A. (2010). Invasive Alien Species of Agricultural Importance in Sri Lanka: Have We Managed Them Properly? In B. Marambe, P. Silva, S. Wijesundara, \& N. Atapattu (Eds.), Invasive Alien Species-Strengthening Capacity to Control Introduction and Spread in Sri Lanka (pp. 115-122). Sri Lanka: Biodiversity Secretariat of the Ministry of Environment.

Wilcove, D. S., Rothstein, D., Dubow, J., Phillips, A., \& Losos, E. (2000). Leading Threats to Biodiversity: What's Imperiling U.S. Species. In B. A. Stein, L. S. Kutner, \& J. S. Adams (Eds.), Precious Heritage: The Status of Biodiversity in the United States (pp. 239-254). New York: Oxford University Press.

Wild Taina Safaris (2019). Getting to Know the Burigi-Chato National Park. https://www.wildtainasafaris.co.tz/burigi-chato-national-park

Witkowski, E. T. F., \& Wilson, M. (2001). Changes in Density, Biomass, Seed Production and Soil Seed Banks of the Non-Native Invasive Plant, Chromolaena odorata, along a 15 Year Chronosequence. Plant Ecology, 152, 13-27.

https://doi.org/10.1023/A:1011409004004

World Weather Online (no date). Biharamulo Monthly Climate Averages. https://www.worldweatheronline.com/biharamulo-weather-averages/kagera/tz.aspx

Yumpu (No Date). Maasai Names of the Common Plants and Grasses of Mara Naibosho Conservancy.

https://www.yumpu.com/it/document/view/3480471/maasai-names-of-the-common-p lants-and-grasses-of-mara

Yunana, Y., \& Dahiru, D. (2015). Effect of Aqueous Leaves Extract of Gardenia ternifolia Plant on Carbon Tetrachloride-Induced Hepatotoxicity in Rats. IOSR Journal of Pharmacy and Biological Sciences, 10, 73-82. http://www.iosrjournals.org

Zhang, C., Liu, W., Xu, Z., Cao, H., \& Ye, W. (2006). Responses of Vegetative Growth and Photosynthesis to Temperature in the Invasive Species Alternanthera philoxeroides and Its Indigenous Congener A. sessilis. Journal of Tropical and Subtropical Botany, $14,333-339$. 